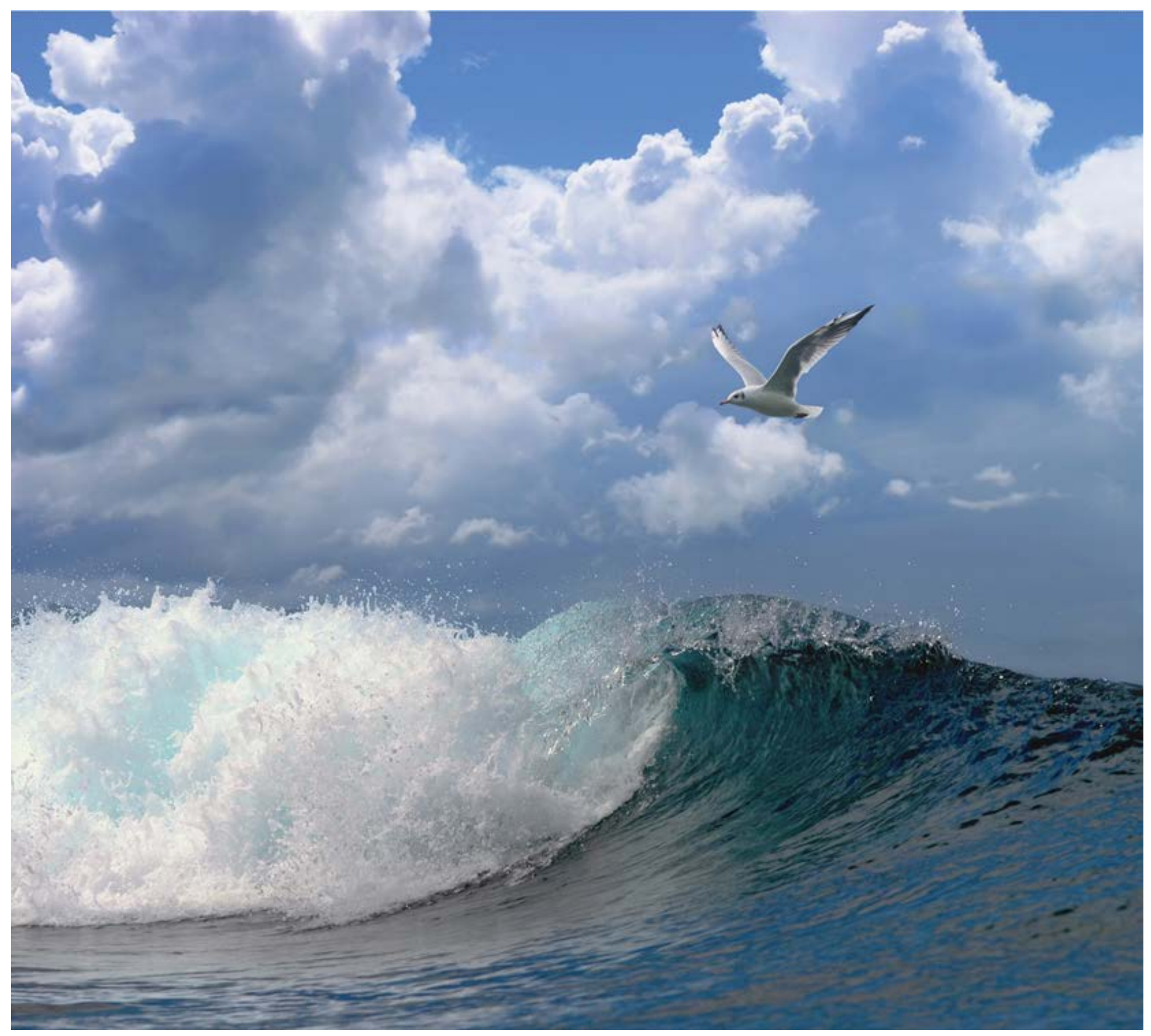

Benthic development around a gas platform in the North Sea - a small scale closure for fisheries

A trait based approach

Authors: Sander Glorius, Ralf van Hal, Klaas Kaag, Babeth van der Weide, Chun Chen, Tobias van Kooten
Wageningen University \&

Research Report C121/16 


\title{
Benthic development around a gas platform in the North Sea - a small scale closure for fisheries
}

\author{
A trait based approach
}

Authors: $\quad$ Sander Glorius, Ralf van Hal, Klaas Kaag, Babeth van der Weide, Chun Chen, Tobias van Kooten

BO-11-018.02-041

Publication date: December 2016

This research project was carried out by Wageningen Marine Research at the request of and with funding from the Ministry of Economic Affairs for the purposes of Policy Support Research Theme Marine Biodiversity (project no. BO-11-018.02-041). 
Sander Glorius, Ralf van Hal, Klaas Kaag, Babeth van der Weide, Chun Chen, Tobias van Kooten, 2016. Benthic development around a gas platform in the North Sea - a small scale closure for fisheries; A trait based approach. Wageningen, Wageningen Marine Research (University \& Research centre), Wageningen Marine Research report C121/16. 422 pp.

Client: $\quad$ Ministry of EZ

Attn.: Anne-Marie Svoboda

PO Box 20401

2500 EK The Hague

The Netherlands

Wageningen Marine Research is ISO 9001:2008 certified.

This report is free to download from https://doi.org/10.18174/400549

Wageningen Marine Research provides no printed copies of reports.

(c) 2016 Wageningen Marine Research Wageningen UR

Wageningen Marine Research The Management of Wageningen Marine Research is not responsible for resulting institute of Stichting Wageningen damage, as well as for damage resulting from the application of results or Research is registered in the Dutch research obtained by Wageningen Marine Research, its clients or any claims traderecord nr. 09098104, related to the application of information found within its research. This report BTW nr. NL 806511618 has been made on the request of the client and is wholly the client's property. This report may not be reproduced and/or published partially or in its entirety without the express written consent of the client. 


\section{Contents}

$\begin{array}{lr}\text { Samenvatting } & 4\end{array}$

$\begin{array}{lr}\text { Summary } & 6\end{array}$

$\begin{array}{lll}1 & \text { Introduction } & 7\end{array}$

2 Materials and Methods $\quad 9$

2.1 Location and history of platform 9

2.2 Sampling method of the benthic community as applied in the Wintershall studies 10

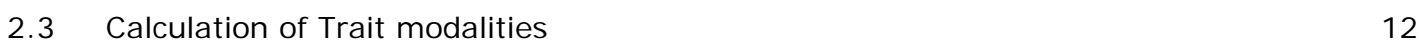

$\begin{array}{lll}2.4 & \text { Benthic dataset } & 13\end{array}$

$\begin{array}{lll}2.5 & \text { Statistical analysis } & 14\end{array}$

$\begin{array}{llr}3 & \text { Results } & 16\end{array}$

$\begin{array}{lll}3.1 & \text { Occurrence of trait modalities } & 16\end{array}$

$\begin{array}{ll}3.2 & \text { Development inside and outside 500m radius } \\ \end{array}$

4 Discussion $r 22$

5 Conclusions and recommendations $\quad 24$

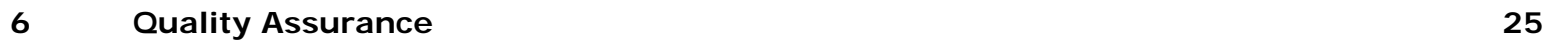

$\begin{array}{lr}\text { References } & 26\end{array}$

$\begin{array}{lr}\text { J ustification } & 28\end{array}$

$\begin{array}{llr}\text { Annex } 1 & \text { Stations sampled in period } 1999-2014 & 29\end{array}$

$\begin{array}{llr}\text { Annex } 2 & \text { Traits and categories } & \mathbf{3 0}\end{array}$

$\begin{array}{lll}\text { Annex } 3 & \text { Linking species to trait modalities } & 31\end{array}$

Annex $4 \quad$ Mean amount of species per phylum and year 33

$\begin{array}{lll}\text { Annex } 5 & \text { Orientation centroids per year } & 34\end{array}$

Annex $6 \quad$ Development of significant modalities $\quad 35$ 


\section{Samenvatting}

In dit project is onderzocht wat het effect is van het sluiten van een gebied voor visserij op de ontwikkeling van de benthosgemeenschap in dit gebied. Hiervoor is een bestaande dataset gebruikt over de periode 1999 tot 2014, opgezet in het kader van een effectenstudie rondom het gasplatform A6-A in opdracht van Wintershall Holding $\mathrm{GmbH}$. Het gesloten gebied was een $500 \mathrm{~m}$ zone rondom een gasplatform dat geïnstalleerd is in 1999. Het platform staat op een ondergrond van fijn zand, bij een waterdiepte van circa $47 \mathrm{~m}$ in het Duitse deel van de Doggersbank. In het jaar voor de sluiting (1999) en in de 15 jaren erna is de benthosgemeenschap met variërende intensiteit bemonsterd met behulp van een boxcore. De data zijn opgeslagen in de Wageningen Marine Research database BEAST.

Binnen dit project zijn de aantallen per soort per monster uit de Wintershall studie gekoppeld aan een database met eigenschappen van het benthos (modalities). De gebruikte database is binnen het BENTHIS project ontwikkeld met als doel effecten van visserijdruk op het functioneren van het benthisch ecosysteem inzichtelijk te maken (Bolam and Eggleton, 2014). Deze database bevat informatie voor meer dan 850 taxa (op genus niveau) voor 10 verschillende modaliteiten welke de levensgeschiedenis, gedrag en morfologie van soorten beschrijven, zoals bijvoorbeeld levensverwachting, mobiliteit en voedselvoorkeur. Door middel van een meta-analyse, waarin gegevens van enkele tientallen visserij impact studies geanalyseerd werden, is deze database van modaliteiten getoetst op gevoeligheid voor visserijdruk. In de studie werden significante relaties gevonden voor alle eigenschappen met uitzondering van de eigenschap morfologie (Sciberras et al., 2014).

Door het combineren van alle eigenschappen van alle soorten op één monsterlocatie wordt het ecosysteem van deze locatie beschreven als een set van functies en eigenschappen (modaliteiten), i.p.v. als een set van soortenabundantie. Dit maakt het mogelijk veranderingen en verschillen in ecosysteem functioneren te onderzoeken.

De resultaten van deze analyses laten zien dat minder dan $4 \%$ van de variatie in eigenschappen tussen het gesloten gebied en het omliggende beviste gebied kan worden verklaard door visserij bij beschouwing van de gehele onderzoeksperiode. Alleen voor soorten die op en in het bovenste deel van het sediment leven, werd een significant effect gevonden, waarbij dichtheden hoger waren in aanwezigheid van visserij. Binnen deze groep organismen is de detritus-etende worm Scoloplos sp. belangrijk, die mogelijk profiteert van de bodemberoering veroorzaakt door visserij.

Terwijl het gebied gesloten was voor visserij hebben er wel platform gerelateerde activiteiten plaatsgevonden die mogelijk een effect hebben gehad op de ontwikkeling van de bodemdiergemeenschap in het gesloten gebied. Dit betekent dat herhaalde metingen in de tijd niet zonder meer onderling vergeleken kunnen worden. Daarom is in een nadere analyse de data opgesplitst in verschillende tijdsperiodes. Hieruit blijkt dat de ontwikkeling van enkele modaliteiten toch significant verschilt tussen het beviste en onbeviste gebied. Deze verschillen zijn echter uitsluitend zichtbaar in één van de tijdsperiodes. De ontwikkeling is dus niet consistent en het waargenomen verschil wordt door jaarlijkse variatie of platform gerelateerde activiteit teniet gedaan. Het waargenomen significante verschil was voor iedere modaliteit een toename in het beviste gebied, met uitzondering van de modaliteit 'ingegraven, welke is toegenomen in het gesloten gebied (alleen in 2014). De modaliteiten die, op enig moment, significant meer in het beviste gebied voorkwamen zijn: soorten die relatief groot en gemiddeld oud worden, zich 'zwemmend' kunnen voortbewegen, zich ingraven in de bodem en geen larvaal stadium kennen. De mobiele soorten zouden mogelijk aan visserij kunnen ontsnappen en/of beviste gebieden snel kunnen koloniseren. Een belangrijke noot hierbij is dat de modaliteit grootte betrekking heeft op de maximale grootte die een genus kan bereiken. Het is mogelijk dat de daadwerkelijk in de monsters aangetroffen individuen klein waren. Dit kan niet onderzocht kan worden omdat lengte niet gemeten werd. Daarnaast is ook het gebruikte tuig niet erg geschikt om grote individuen te bemonsteren. Daarnaast zouden soorten die groot 
kunnen worden ook andere eigenschappen kunnen bezitten die compenseren voor hun gevoeligheid voor bevissing. Ze kunnen bijvoorbeeld dieper in het sediment leven.

Geen van de modaliteiten waarvoor in andere studies negatieve effecten van visserij gevonden werden, zoals soorten die oud kunnen worden, een beschermend 'pantser' hebben (exoskelet, schelp etc.) en soorten die organisch materiaal filteren (van Denderen et al., 2015b), zijn toegenomen in het gebied uitgesloten van visserij.

Er zijn meerdere mogelijke verklaringen voor het onverwacht kleine effect van langdurige visserijuitsluiting rond platform A6-A. Mogelijke verklaringen zijn dat er maar van één jaar voor de installatie van het gesloten gebied gegevens beschikbaar zijn waardoor toevalligheden in dat ene jaar erg bepalend zijn voor de uitkomsten van de analyses. Daarnaast is het monsteraantal afgenomen gedurende het verloop van de studie waardoor de power van de statistische toets om verschillen in ontwikkeling voor de latere jaren aan te tonen lager is. De natuurlijke dynamiek in het gebied (zoals stormen en getijdenstromingen die vergelijkbare invloed op het benthos hebben als visserij) evenals de uitvoering van exploratieve olieboringen in het gesloten gebied kunnen een eventueel verschil in ontwikkeling mogelijk deels dan wel geheel teniet hebben gedaan. 


\section{Summary}

This project looked at the effect of closing an area for fisheries on the development of the benthic community. An existing data set of benthic species densities sampled at different distances and angles from a platform was used for this purpose. The particular area was closed due to the installation of a gas production platform, but is likely to function as a marine protected area (MPA), with the expectation that the benthic community develops differently from the benthic community in the surrounding areas as it no longer has to cope with the impact of fisheries. Differences in development might be linked to the impact of fisheries and the effects of closure might provide an expectation for the effect of planned MPAs in similar areas.

The gas platform A6-A is situated in the north eastern part of the Doggerbank in the North Sea and was constructed in 1999 with a $500 \mathrm{~m}$ zone closed for fisheries around it. The benthic community in the $500 \mathrm{~m}$ zone and in areas outside this zone have been monitored with a variable intensity prior and in the 15 years after installation using a boxcorer. The boxcorer samples have been analysed to species level and the abundance of each species is linked to a dataset containing specifications of the benthic species (trait modalities). This dataset contains information for over 850 taxa (genus level) for 10 different modalities describing e.g. life history, morphology and food preferences. These modalities were selected on their sensitivity for fishery impact (Sciberras et al., 2014). In this approach, species are characterized by their ecological functions and properties, and the ecosystem is reformulated as a set of functions and properties (or 'trait composition'), rather than by a collection of species abundances.

The results of the trait analyses indicate that less than $4 \%$ of the variation in trait groups and their corresponding modalities between the closed area and the surrounding fished area can be explained by fisheries considering the whole research period. In terms of individual trait modalities, we find that only the modality which includes species that live on top and/or in the upper part of the sediment responds significantly and positively to exposure to fishing. This was largely caused by the genus Scoloplos sp. (Annelida) which is a detritivores worm that might profit from the sediment disturbance caused by fishing.

While the area was closed for fisheries, activities related to the platform have taken place potentially affecting the development of the benthic community. To take consider this, the analyses were executed for different time periods after closure. These analyses revealed that some trait modalities development differently between the fished and none-fished sample group in a certain time period, disappearing in consecutive sampling events. Modalities for which differences did occur at certain time periods include 'Size range - 101-200', 'Larval development location - direct', and 'Mobility - swim' which have all, except one, increased (more) in the area open for fisheries. The only exception is the modality 'Living habitat - burrow', which has increased more in areas closed to the fishery. Contrary to expectations, larger sized species have increased in samples taken in the fished area, but as the trait defines the maximum size of a particular genus and species lengths were not recorded it could not be checked if individuals were relative small. No modalities that have found to have a negative relationship with trawl disturbance in other studies, such as long lived, hard bodied and suspension feeding organisms (van Denderen et al., 2015b) have increased in the area from which fishing was excluded.

Hence, there is no clear indication of a difference in development in the benthic community in and outside the closed zone that can be linked to excluding fisheries from the closed zone. Explanations for a lack of different development in trait modalities between the fished and non-fished area are multiple and include the large weight that is given on the single measurement prior placement of the platform, decreasing sampling effort over time, the influence of natural dynamics within the area and anthropogenic influences (drilling) in the area excluded from fisheries tempering a possible fishing effect. 


\section{Introduction}

In recent years, the Dutch government has increasingly used Marine Protected Areas (MPAs, areas closed to certain human activities, most notably fisheries) as a tool to induce recovery of the flora and fauna of the seabed. Protection of habitats to promote development to an ecologically balanced state driven primarily by natural drivers in order to protect (and recover) biodiversity as well as structure and function are goals for the Marine Strategy Framework Directive, and for implemented Natura 2000 (N2000) areas in the North- and Wadden Sea. In the coastal N2000 areas North Sea Coastal Zone, Vlakte van de Raan, Voordelta and Wadden Sea, areas are already closed to specific types of fisheries. In the offshore N2000 areas Frisian Front, Cleaver Bank and Dogger Bank, as well as in other areas (e.g. Oyster Grounds), zoning is currently ongoing.

The assignment of MPAs is, in the Dutch policy framework, often a result of extensive consultation of and dialogue between the authorities and various stakeholders, in particular fishermen and environmental NGOs. In this system, the authorities set the preconditions, and the stakeholder group develops a proposal representing a reasonable compromise, within the given constraints. It is of crucial importance that there is general agreement among the involved stakeholders that the constraints under which they are asked to operate are valid and sensible.

On a European level the Dutch government has committed itself to closing a part of the Dutch Continental Shelf to fisheries through the implementation of MPAs. While there are countless studies showing indications of rapid recovery of certain taxa, biodiversity, biomass and other properties of the ecosystem, very few of these studies are directly comparable to the situation on the Dutch Continental Shelf.

The direct effects of the most prevalent types of fishing gear on the North Sea seafloor habitat and its ecosystem have been shown (van Denderen et al., 2014, Bolam et al., 2014, Bergman and van Santbrink, 2000, Depestele et al., 2015), but the recovery after fishing stops is less obvious. For example, five years after the establishment of an offshore wind farm, which is off limits to all vessels, no difference in the development of benthic communities between the effective MPA and surrounding area could be established (Bergman et al., 2015).

The North Sea is a productive sea, and as a consequence is heavily fished. Most of the area is subject to at least one type of fishing, and areas which are not heavily fished are generally unsuitable for the fishing gear used due to prevailing abiotic conditions (e.g. depth, bottom type). The same difference in abiotic conditions makes it difficult to compare these unfished areas to other, fished areas: they differ in much more than only the fishing intensity, and hence differences in the local ecosystem cannot be attributed to fishing alone (van Denderen et al., 2014). As a result, little is known about the unfished state of the currently fished areas in the North Sea.

Wind farms and other offshore structures, such as oil and gas installations, provide unintended testing grounds for the recovery potential of closed areas in the North Sea, as they are often closed for longer periods of time (>10 years), and have extensive monitoring effort associated with their Environmental I mpact Assessment requirements. It is important that the data from these EIA's are used to assess the suitability of MPAs to allow for recovery of the benthic ecosystem, to minimize uncertainty. Leaving these data un-analysed (and hence not fully using available information) may frustrate the ongoing stakeholder consultation and participation towards zoning of the Dutch Continental Shelf. One such closed area, the offshore wind farm OWEZ, was recently analysed and no effect were found on the benthic ecosystem after 5 years of closure to all types of fisheries (Bergman et al., 2015). However, this wind farm is located in a relatively shallow area with course sands and high degree of natural disturbance (as a result of wave and current action). It was recently shown that the benthic ecosystem in such areas generally shows little response to bottom trawling disturbance, compared to more stable, deeper areas with finer sediments (van Denderen et al., 2016), and if the trawling does not lead to a changed ecosystem, recovery can hardly be expected after trawling is banned. 
In recent years, as discussed monitoring effort directed at the benthic ecosystem has taken place in areas that became closed for fisheries, e.g. wind farms and oil and gas platforms. Some of these data have been analysed in relation to their status as MPAs (Bergman et al., 2015, Lindeboom et al., 2011, Beare et al., 2013). However, not all datasets have been analysed and reported upon, nor has the Dutch ministry of Economic Affairs seen a consistent overview of the results of these and other international studies. The ministry of Economic Affairs therefore requested to firstly look for other datasets that could be processed and analysed. The second assignment was to incorporate this new information in a review of existing studies on the effect of closed areas on the benthic community. In this study answers the first assignment. Here, we analyse a dataset of benthic samples in a closed area around a gas production platform. This platform is located in a relatively deep part of the German Continental Shelf $(40-55 \mathrm{~m}$ ), in an area with relatively low natural disturbance and fine sediment. Furthermore, the last sampling has taken place 15 years after the area was closed to fishing in 1999. In this area, effects of bottom trawling on the benthic fauna have been found in naturally existing gradients (van Denderen et al., 2014). These factors together make it more likely that recovery has actually occurred in this area.

We have analysed the effects of the area closure using Biological Trait Analysis. In this approach, species are characterized by their ecological functions and properties, and the ecosystem is reformulated as a set of functions and properties (or 'trait composition'), rather than by a collection of species abundances. Two major advantages of replacing species by their functions and properties is that (1) it makes results more comparable among sites, which may have very different species assemblages, but are likely to be more similar in terms of trait composition, and (2) it allows us to develop a mechanistic understanding between certain species characteristics (e.g. burying depth, maximum body size) and sensitivity to fishing. Such mechanistic understanding allows for rapid evaluation of the fishing sensitivity of other species, for example those which are no longer found in the area, but which may be able to recover eventually after fishing stops. This method has been used successfully to study the effects of bottom trawling on benthic ecosystems (van Denderen et al., 2015a, Tillin et al., 2006). 


\section{Materials and Methods}

\subsection{Location and history of platform}

In this study data were used that were previously commissioned by a consortium consisting of Wintershall Holding GmbH, EMPG, RWE Dea and EWE AG operating platform A6-A. From here on, this study is referred to as the Wintershall study. The platform is situated in the German EEZ in the north eastern part of the Dogger Bank in the North Sea (coordinates 55o 47' 34.72" N, 3o 59' 39.88" E), see Figure 2-1). The average water depth in the platforms' vicinity is around 47 meters with a dominant current in NW-SE direction. The area surrounding the platform can be characterized as being homogenous and sandy. The area is subject to intensive fishing activity (Figure 2-2), indicated by beam trawl imprints in the sediment (Figure 2-5).

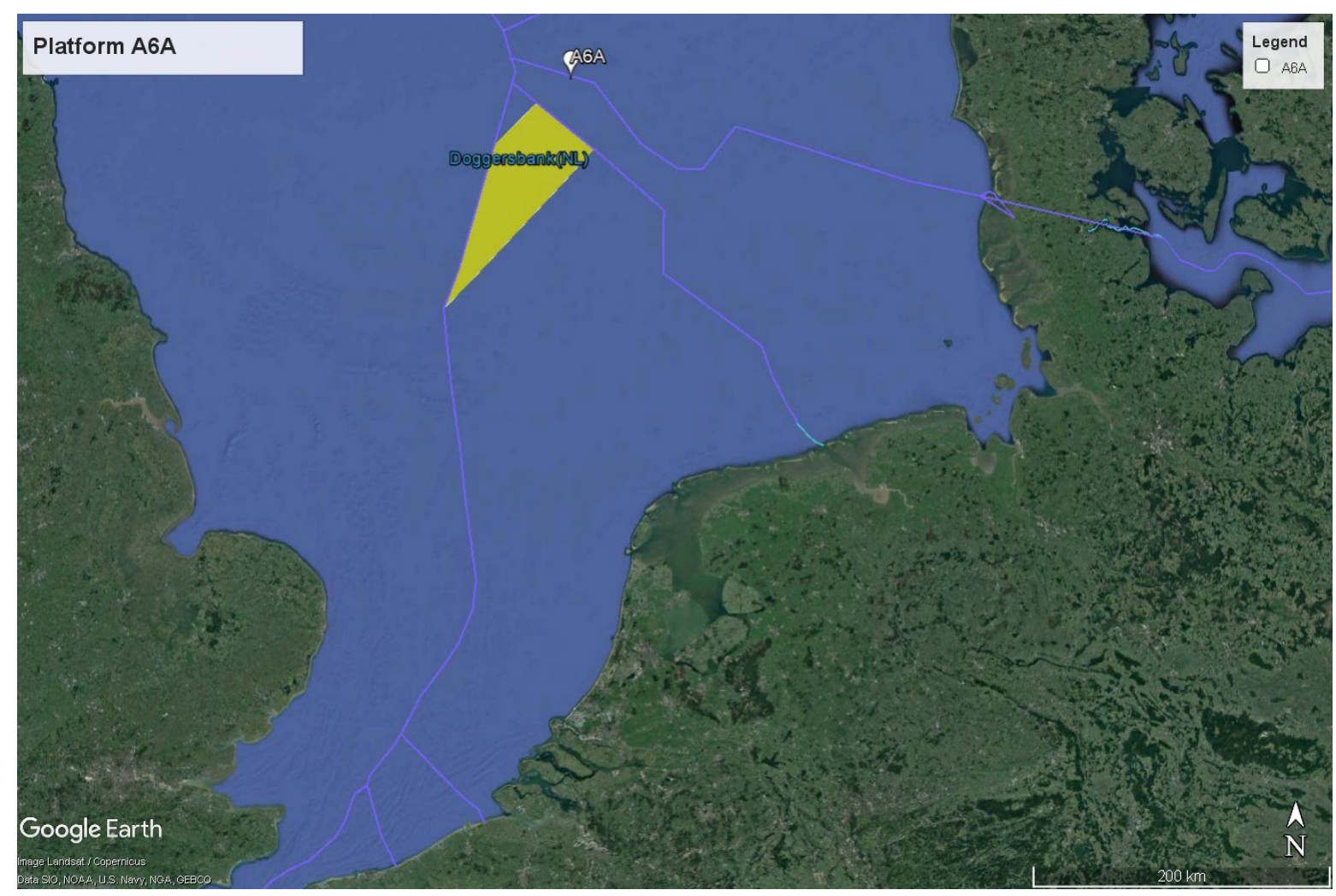

Figure 2-1 Location platform A6-A in relation to the Dutch Natura 2000-site Dogger Bank. Source Google Earth.

The platform was installed in 1999, after which exploitation of natural gas started. Since the start of construction, a safety zone of $500 \mathrm{~m}$ around the platform is closed to all fishing vessels.

After placement, several drilling activities were carried out in order to put new wells into production. Drilling activities were carried out in the period 1999-2000, in 2005 and in 2012-2014. 


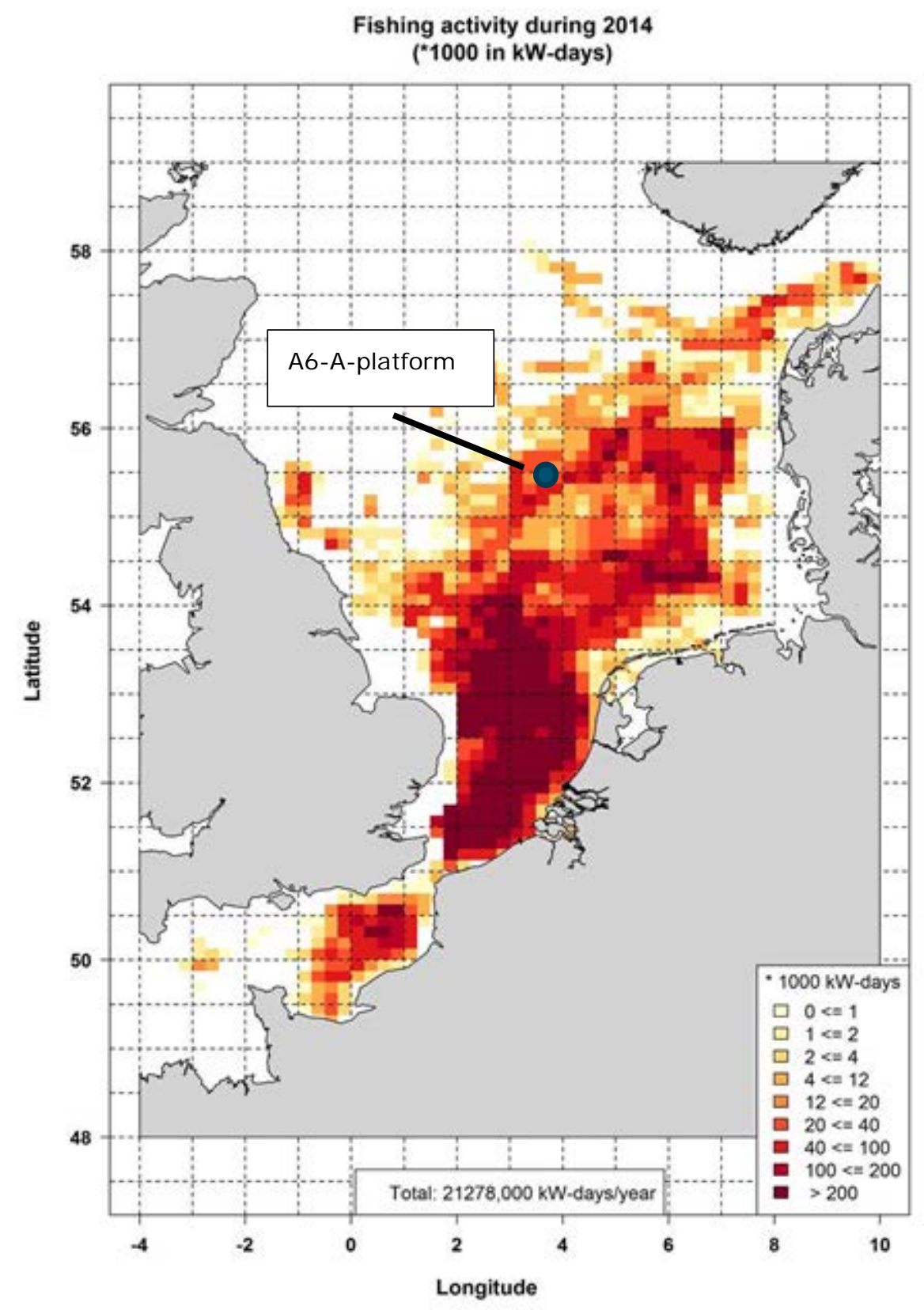

Figure 2-2 Fishing activity (in * $1000 \mathrm{~kW}$-days) for all Beam, Otter and pair trawl gears (excluding shrimp fisheries) together in 2014 (van der Reijden et al. 2016).

\subsection{Sampling method of the benthic community as applied in the Wintershall studies}

In the Wintershall study, benthic samples were taken using a Reineck boxcorer $\left(0.07 \mathrm{~m}^{2}\right)$. The first benthic samples were taken in 1999 before the platform was installed. After installation of the platform, additional benthic samples were taken in 2000, 2001, 2006 (after drilling), 2011 (before drilling) and 2014 (after drilling).

The sampling stations were oriented in concentric circles around the platform, at distances of 125, 250, 500, 1000 and $2000 \mathrm{~m}$ from the platform (Figure 2-3). Four stations were situated at angles of 45, 135, 225 and 315 degrees. Two additional stations each were located at $1 \mathrm{~km}$ distance (at angles of 90 and 180 degrees) and $2 \mathrm{~km}$ distance (at 90 and 180 degrees). There was one additional 
references station at $4 \mathrm{~km}$ (135 degrees) and from 2011 onwards an additional 2 reference stations located at $10 \mathrm{~km}$, at 0,180 and 290 degrees were included in the sampling grid.

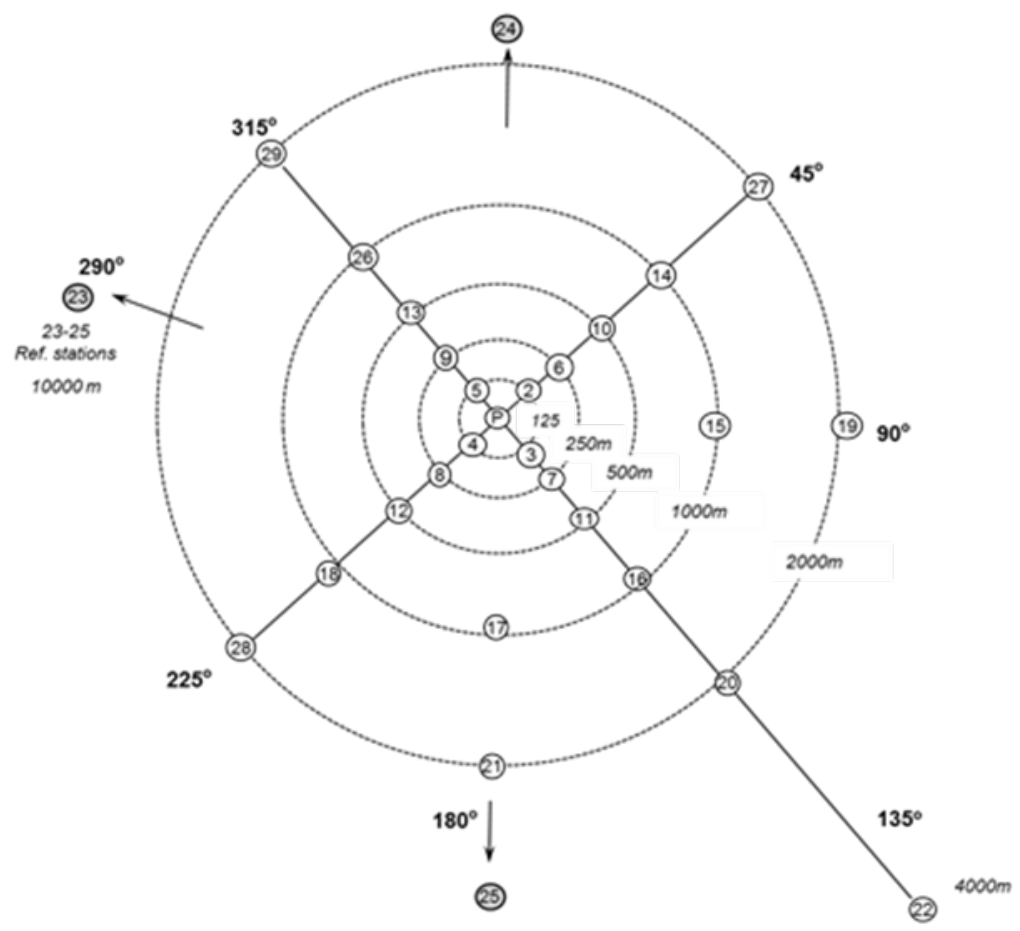

Figure 2-3 Schematic presentation of the sample locations. Platform A6-A is located in the centre (depicted with the symbol ' $\mathrm{P}$ ').

Sampling intensity has changed over the years. The number of replicates taken (and analysed) per sample location was reduced from 5-10 to 1 while the amount of sample locations slightly increased, see table 2.1. In Annex 1 an overview is given of the amount of samples that were analysed per sample location and year.

Table 2.1 Number of samples analysed and replicates per year.

\begin{tabular}{|c|c|c|}
\hline Year & Tot. nr. samples & Replicates* \\
\hline 1999 & 125 & $5-10$ \\
\hline 2000 & 120 & $5-10$ \\
\hline 2001 & 120 & $5-10$ \\
\hline 2006 & 66 & $3-5$ \\
\hline 2011 & 25 & 1 \\
\hline 2014 & 31 & $1-2$ \\
\hline
\end{tabular}

* depending on sample location, see Annex 1.

Benthic sampling process

A boxcorer consists of a frame in which a cylindrical pot is situated in the middle, see Figure 2-4.

Several weights are connected to the pot to push it into the sediment once situated on the seafloor. A blade, attached to a steel plate, is moved under the pot to trap the sediment during recovering. The sampling area of the boxcorer is approximately $0.07 \mathrm{~m}^{2}$. Leaking pots or pots with a penetration depth less than $15 \mathrm{~cm}$ were rejected and a new boxcorer sample was taken.

On deck the box was removed from the corer frame and placed above a sieve with a mesh size of 1 $\mathrm{mm}$. Any water standing above the sediment in the box was removed and a photograph (Figure 2-4) was taken of the sediment surface together with information of the station (number and location). The distance between the top of the box and sediment surface was measured and noted. The pot was 
removed and the depth of the oxidized layer was measured and recorded together with some basic characteristics of the sediment.

The material was rinsed with sea water over a sieve with a mesh size of $1 \mathrm{~mm}$, to remove sand and clay particles. From the remaining material (biota, shells, stones and other particles) a photograph was taken, after which the sample was stored in a polyethylene container. The sample was preserved with 6-10\% buffered formaldehyde in seawater solution.

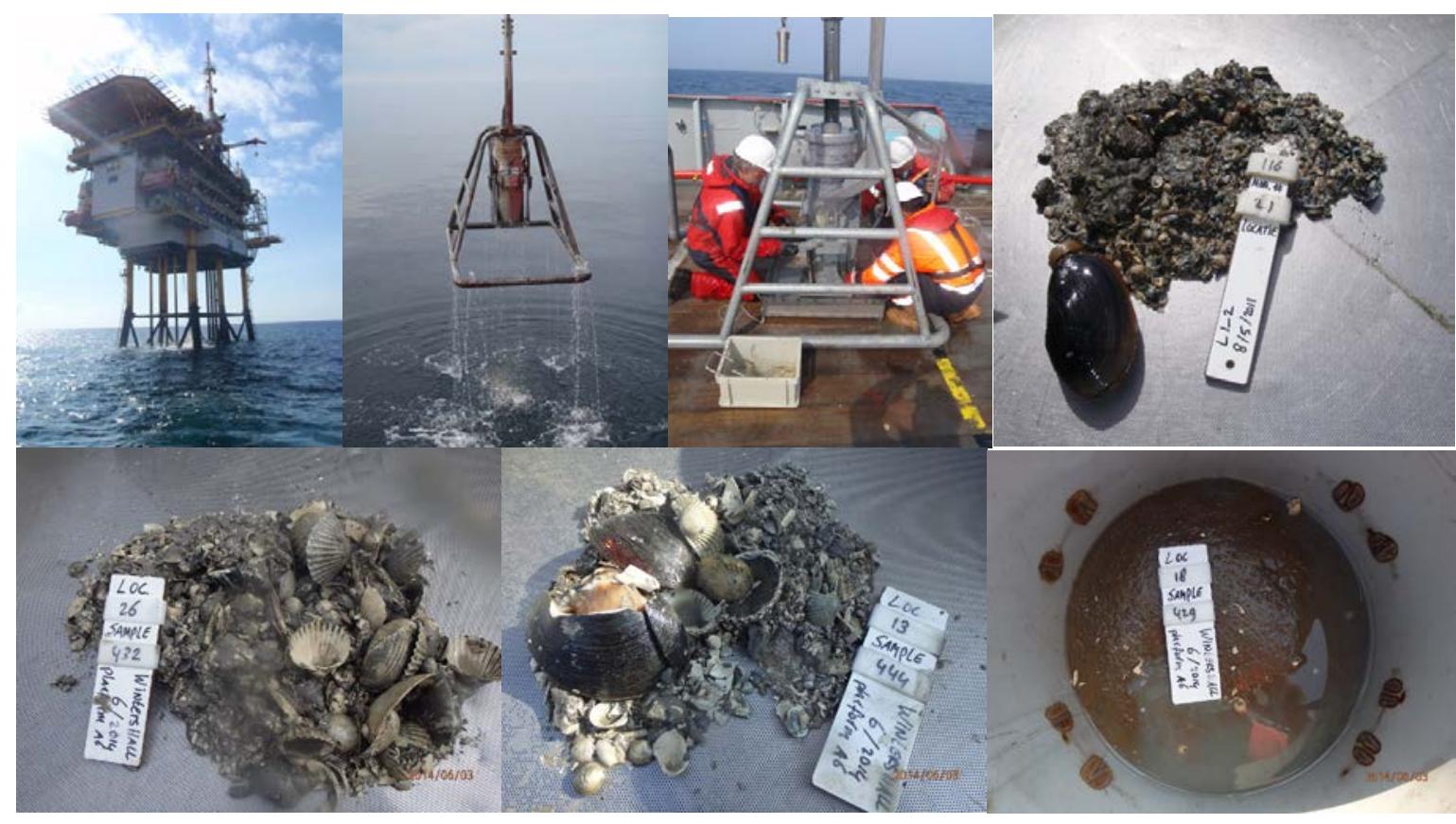

Figure 2-4 Impression of fieldwork for the Wintershall study. Top panel, platform A6-A, box corer and boxcorer sample. Bottom panel boxcorer samples.

Macro fauna characterisation

Collected macro fauna was examined and identified by making use of a stereomicroscope. Standard taxonomic keys and references were used to identify each taxon. The sampled organisms were identified to the lowest taxonomic level possible (WoRMS Editorial Board 2014). The number of individuals of each taxon was determined. Specimen that could not easily be identified were kept aside for further examination. Juveniles whose species-specific features were not sufficiently developed and damaged species, were identified to a higher taxonomic level.

Examples of the benthic species were taken up in the Taxonomic Reference Collection that has been maintained for several years at Wageningen Marine Research as part of their Quality Assurance procedures.

\subsection{Calculation of Trait modalities}

The taxonomic data collected at all sampling stations in the Wintershall study was coupled to an infaunal trait database (Bolam and Eggleton, 2014). This biological database comprises 10 different traits (Table 2.2). Each trait is subdivided into multiple modalities (categories) and in Annex 2, all modalities of the 10 traits and corresponding codes (used in the analysis) are provided. These traits were selected and tested to assess effects of fishery pressure within the BENTHIS research program (www. benthis.eu \& Sciberras et al., 2014 \& Bolam et al., 2013).

The trait database essentially consists of a large list of genera, with a column added for each trait modality. Each of these modalities is then by a "fuzzy coding" approach assigned a score between 0 and 3, depending on the affinity of that taxon for that modality. A 0 means 'no affinity', 1 or 2 expresses 'partial affinity' and 3 means ' total and exclusive affinity'. In reality, specific traits such as 
size range, longevity, and larval and egg development were predominantly expressed as partial modalities for most taxa while, in contrast, entries for other traits were often represented by a total affinity for one particular modality. These scores are normalized within a trait and the normalized score is multiplied by the density (numbers $/ \mathrm{m}^{2}$ ) of the specific genus. This yields the final 'trait by sample' matrix, which describes each sample as a distribution of densities over modalities. This matrix is the basis for further analysis.

In total 308 different taxonomic units were collected in the boxcorer samples. Taxa that were, as a consequence of growing expertise, not determined for the whole sampling period (1999-2014) (e.g. Bryozoa and Hydrozoa) were excluded for analysis $(n=21)$. Of the remaining taxonomic units $(n=287)$ a linkage was made with the trait dataset to create the 'trait by sample' matrix. Not all collected taxa were present in the trait dataset, in these cases higher taxonomic levels were used. In Annex 3 a list of taxa and subsequent actions are provided for taxa that could not be linked directly to the trait database.

Taxon densities, expressed as number of species per square meter, were square root transformed prior to calculation of the trait modalities in order to put less emphasis on taxa occurring at high densities.

Table 2.2 Traits and definitions, slightly adapted from Bolam et al. (2014).

\begin{tabular}{|c|c|}
\hline Traits & Trait Definition and functional significance \\
\hline SizeRange (mm) & $\begin{array}{l}\text { Relates to organic matter transfer in ecosystem. Large organisms hold organic } \\
\text { matter (low turnover) within the system relative to small-bodied species (high } \\
\text { turnover) (Pearson and Rosenberg, 1978). Furthermore, catchability is size } \\
\text { dependent. Also, if a species is larger, and thus heavier, it will be less prone to the } \\
\text { bow wave of the gear. }\end{array}$ \\
\hline Morphology & Relates to species sensitivity. External characteristics of the taxon. \\
\hline Longevity (years) & $\begin{array}{l}\text { Maximum reported life span of the adult stage. A proxy for relative } r \text { - and K- } \\
\text { strategy of the species (Pearson and Rosenberg, 1978). }\end{array}$ \\
\hline Larval development & $\begin{array}{l}\text { Indicates the potential for dispersal of the larval stage. Affects ability to recover } \\
\text { from disturbance with planktonic recruitment affording potentially faster } \\
\text { recolonization than direct development (Thrush and Whitlatch, 2001). }\end{array}$ \\
\hline Egg development & $\begin{array}{l}\text { Indicates dispersal via the egg stage and the potential susceptibility of eggs to } \\
\text { damage from fishing. Benthic eggs are generally more concentrated over smaller } \\
\text { areas. Asexual reproduction allows the potential to increase numbers rapidly, } \\
\text { particularly following disturbance. }\end{array}$ \\
\hline Living habitat & $\begin{array}{l}\text { Indicates potential for the adult stage to evade, or to be exposed to, physical } \\
\text { disturbance. }\end{array}$ \\
\hline Sediment position & $\begin{array}{l}\text { Typical living position in sediment profile. Organisms occupying shallower positions } \\
\text { in the sediment are more likely to contact trawl gear than those living deeper. } \\
\text { Sediment position also has implications for the effect of the organism to affect } \\
\text { sediment-water nutrient and/or oxygen exchange. }\end{array}$ \\
\hline Feeding type & $\begin{array}{l}\text { Feeding mode has important implications for the potential for transfer of carbon } \\
\text { between the sediment and water and within the sediment matrix. Feeding mode } \\
\text { also has important repercussions for many biogeochemical processes (Rosenberg, } \\
\text { 1995). }\end{array}$ \\
\hline Mobility & Mobility affects the ability for adult recolonization of disturbed areas. \\
\hline Bioturbation & $\begin{array}{l}\text { Describes the ability of the organism to rework the sediments. Can either be } \\
\text { upward, downward, onto the sediment or mixing of the sedimentary matrix. } \\
\text { Bioturbation mode has important implications for sediment-water exchange and } \\
\text { sediment biogeochemical properties. }\end{array}$ \\
\hline
\end{tabular}

\subsection{Benthic dataset}

The benthic data are stored in the BEAST database of I MARES. Consistency of the macro fauna species determination over the years was checked by analysing the trend in sample mean richness and density for all sampling years. The mean number of taxonomic units increased over the years while the mean densities (although showing some fluctuations) did not decrease or increase over time, see 
Annex 4. An increase in experience of the laboratory assistants and developments in taxonomy (e.g. splitting species) resulted most likely in the increase in number of different taxa determined. As the mean density was stable and the taxonomic units were to be converted to trait-modalities the resulting species pool was considered consistent over the years.

The zone excluded from fishery (names in this report as 'inside') consists of a circler area with a radius of $500 \mathrm{~m}$ from the platform location. Station numbers 2 till 9 are located within this zone, see area marked in red in Figure 2-5. The zone prone to fishery stretched form 500 till $1000 \mathrm{~m}$ away from the platform (names in this report as 'outside'). The station numbers 14 till 18 and 26 are located within this zone, see area marked in blue in Figure 2-5. Sampling stations located at a distance of precisely $500 \mathrm{~m}$ of the platform were excluded as these are situated on the border of the fishery zone making it unsure if these are fished or not. On a side scan sonar mosaic made in sampling year of 2014 clear trawl imprints can be seen outside the 500m zone, see Figure 2-5 (see St 11 and 13, where in 2014 tracks were visible within the $500 \mathrm{~m}$ zone). The side scan sonar mosaic made in 2011 shows also fish activity outside the $500 \mathrm{~m}$ zone. It would require a detailed study of the VMS (Vessel Monitoring System) records to determine the actual amount of fishing occurring in the area.

Due to an alteration in exact position of the platform in 2000, the monitoring in 1999 was off for about $200 \mathrm{~m}$. Sampling station numbers in that year have been adjusted in such a way that they were comparable with inside and outside sampling stations in later years.

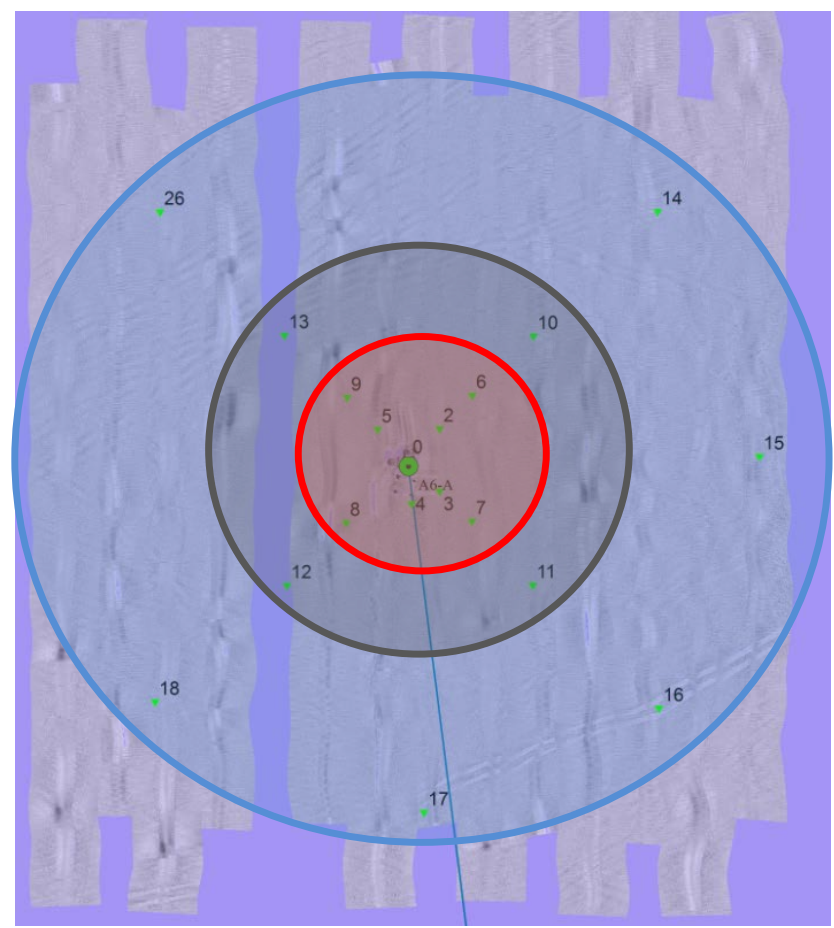

Figure 2-5 Side scan sonar image showing morphology around the platform and traces of fishery trawl marks in the sand $(2 \times 2 \mathrm{~km})$ (Glorius et al., 2015). The red circle marks the 'inside' zone (0-500 $\mathrm{m})$, the blue the 'outside' zone (500-1000 m) and excluded stations are marked by a grey circle.

\subsection{Statistical analysis}

Constrained correspondence analysis

The effect of exclusion of fisheries on the development of trait modalities was analysed using constrained correspondence analysis (CCA). Constrained correspondence analysis is a method to extract and summarise variation in a set of response variables that can be explained by a set of explanatory variables. We used time ('before'; sampling year is 1999, and 'after'; all sampling years after 1999) and location (inside the fishery enclosure zone, and outside the enclosure zone) as explanatory variables. The explanatory dataset is constructed in such a way that it explains as much as possible the variation in the density-modality dataset in order to invest sensitivity of the modalities- 
dataset to the constrains. The multivariate analyses were done using the package vegan in $\mathrm{R}$ (Oksanen et al., 2013).

Univariate analysis

Trait modalities that show a different development between the two sampling areas were examined further, using a linear mixed model as shown below:

$$
\text { modality }_{i j}=\beta_{0}+\beta_{1} \times \text { time }_{i j}+\beta_{2} \times \text { area }_{i j}+\beta_{3} \times \text { time }_{i j} \times \text { area }_{i j}+\alpha_{i}+\varepsilon_{i j}
$$

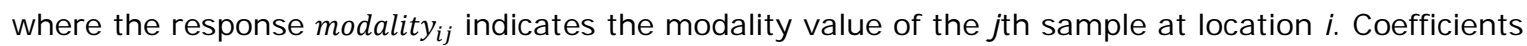
$\alpha_{i}$ accounts for the dependency of samples at the same location and it follows a normal distribution. Additionally, the random error $\varepsilon_{i j}$ follows a normal distribution. In the model, modality is a linear function of time (before 0 vs. after 1 ) and area (in 0 vs. out 1 ). The null hypothesis is that the development in modality is similar for the 'inside' and 'outside' zone. Thus the coefficient of the interaction term $\beta_{3}$ in the model is zero. To test the null hypothesis, ANOVA using chi-squared test was applied. A p-value of $<0.05$ implies a statistical significantly different modality change pattern (before and after) between closer and further sample locations. 


\section{$3 \quad$ Results}

\subsection{Occurrence of trait modalities}

Almost all modalities are present in $>50 \%$ of the samples (Figure $3-1$ ). Five modalities have a presence below $10 \%$ and were excluded for further analysis. Four of them belong to the trait Morphology namely; Stalked, Cushion, Crustose and Tunic. In this trait category only the modalities soft bodied and exoskeleton remain in the dataset.

\section{Distribution of trait modalities in dataset}

density

occurrence
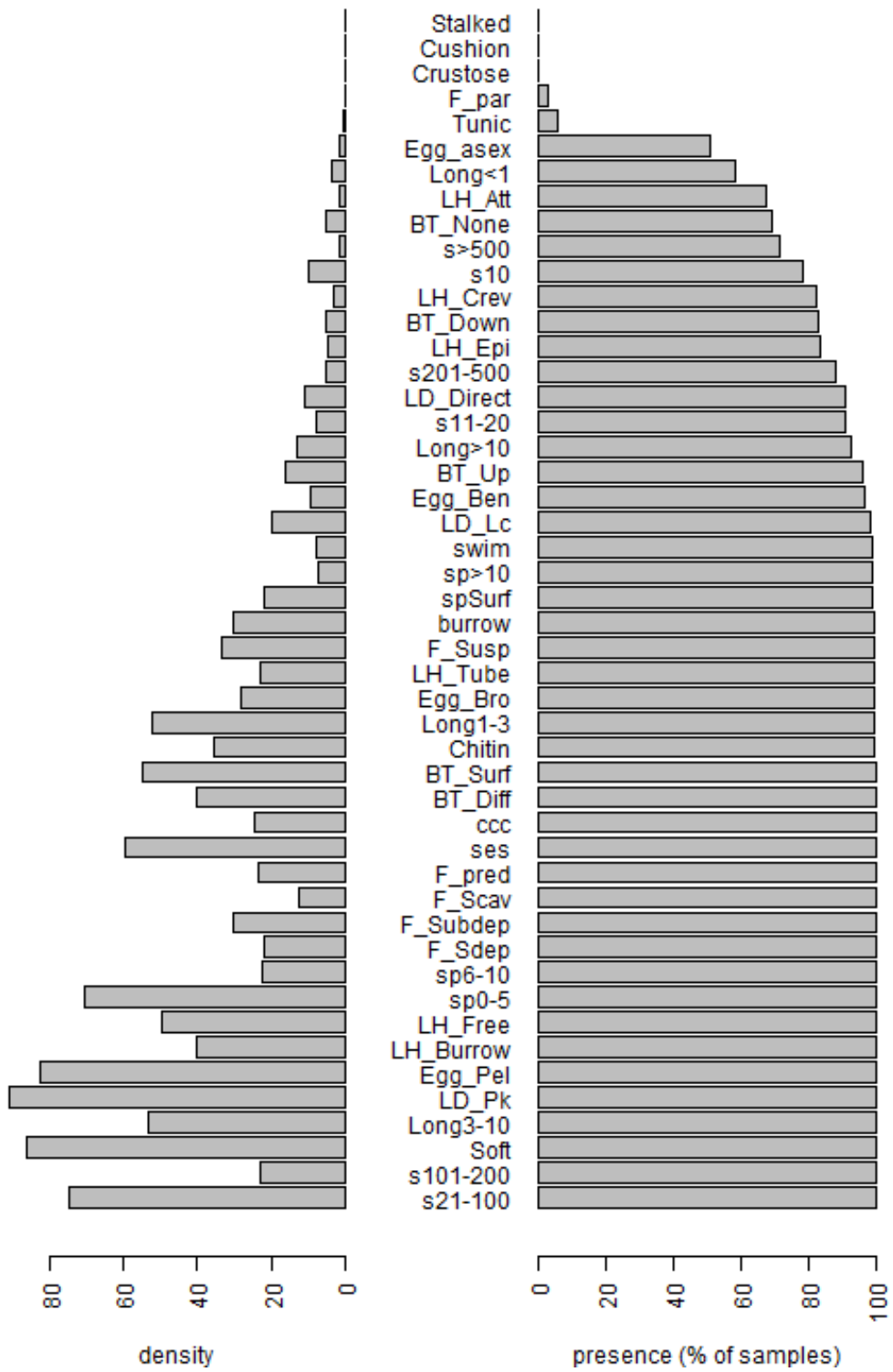

Figure 3-1 Density (left) and occurrence (right) of modalities in dataset (all years, $n=251$ ). 


\subsection{Development inside and outside $500 \mathrm{~m}$ radius}

The result of the constrained correspondence analysis (CCA) is shown in Figure 3-2. The centroids of the stations excluded for fisheries sampled within the $500 \mathrm{~m}$ zone ('inside') and for the stations exposed to fishery located at $1000 \mathrm{~m}$ from the platform ('outside') are plotted for both before ('before') placement of the platform and after ('after') placement of the platform. The distance between inside and outside centroids before the presence of the platform is roughly the same as it is after placement of the platform indicating that the difference between the zones has not increased. Striking is the relative large difference between the zones in 2001, see also ordination plot in Annex 5 .

The explanatory variables Time (before and after) and Area (inside vs outside) explain only $3.7 \%$ of the variation in the modality dataset. Taxon densities within the modalities SizeRange 10-20, SizeRange $>500$ and Downward conveyor have increased in importance within the inside zone. Outside the $500 \mathrm{~m}$ zone densities within the modalities Attached to bed (Living habitat), Epi/endo zoic/phytic (Living habitat), Suspension (Feeding mode), Asexual (Egg development location) and None (Bioturbation) have increased in importance. Of these modalities only Epi/endo zoic/phytic (Living habitat) developed significantly different between the zones, see table 3.1 and Figure 3-3.

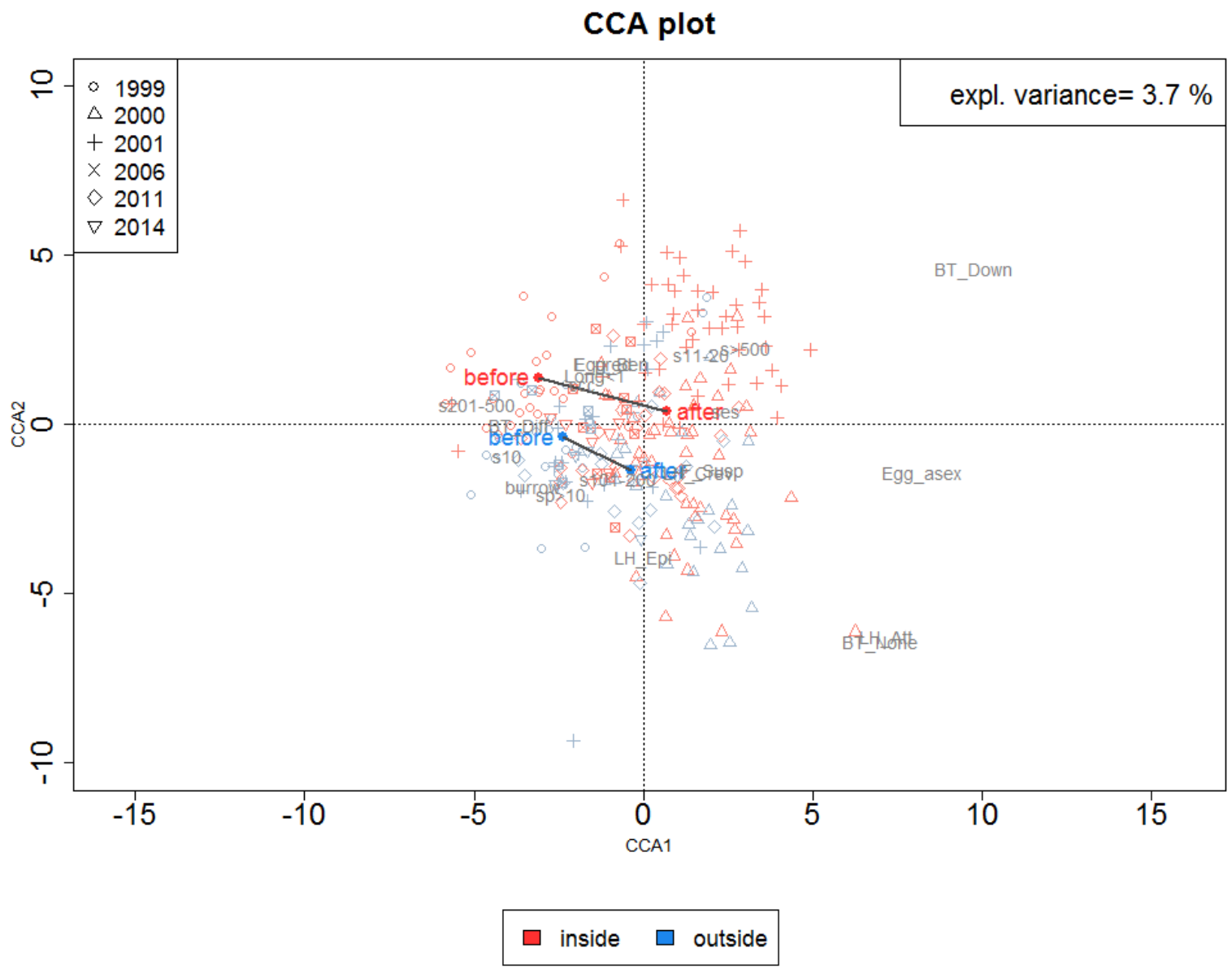

Figure 3-2 Constrained correspondence analysis plot of the trait modalities. Modalities are 30 fold magnified over the CCA1 and CCA2 axis. Only the 20 modalities that show largest variation between the zones (and times) are shown in grey. Influence of time $(p=0.001)$, influence of zone $(p=0.19)$. Sample stations that are located inside the $500 \mathrm{~m}$ zone are depicted in red and sample station at a distance of $1000 \mathrm{~m}$ from the platform are depicted in blue. 
Table 3.1 Modalities that increased in importance after impact per zone based on the CCA ordination plot and $\mathrm{p}$-values of plot $\mathrm{x}$ time interaction. $* *$ being significant $(\mathrm{p}<0.05)$.

\begin{tabular}{llll}
\hline Zone & Trait & Modality & p-value \\
\hline Inside & Bioturbators & Downwards conveyer & 0.1886 \\
& SizeRange & $>500$ & 0.6007 \\
& SizeRange & $10-20$ & 0.3793 \\
\hline Outside & Bioturbators & None & 0.1234 \\
& LivingHabit & Att. to substratum & 0.6699 \\
& LivingHabit & Epi/endo zoic/phytic & $0.0064^{* *}$ \\
& FeedingMode & Suspension & 0.9519 \\
& EggDevLoc & Asexual/Budding & 0.7054 \\
\hline
\end{tabular}

LivingHabit Epi/endo zoic/phytic
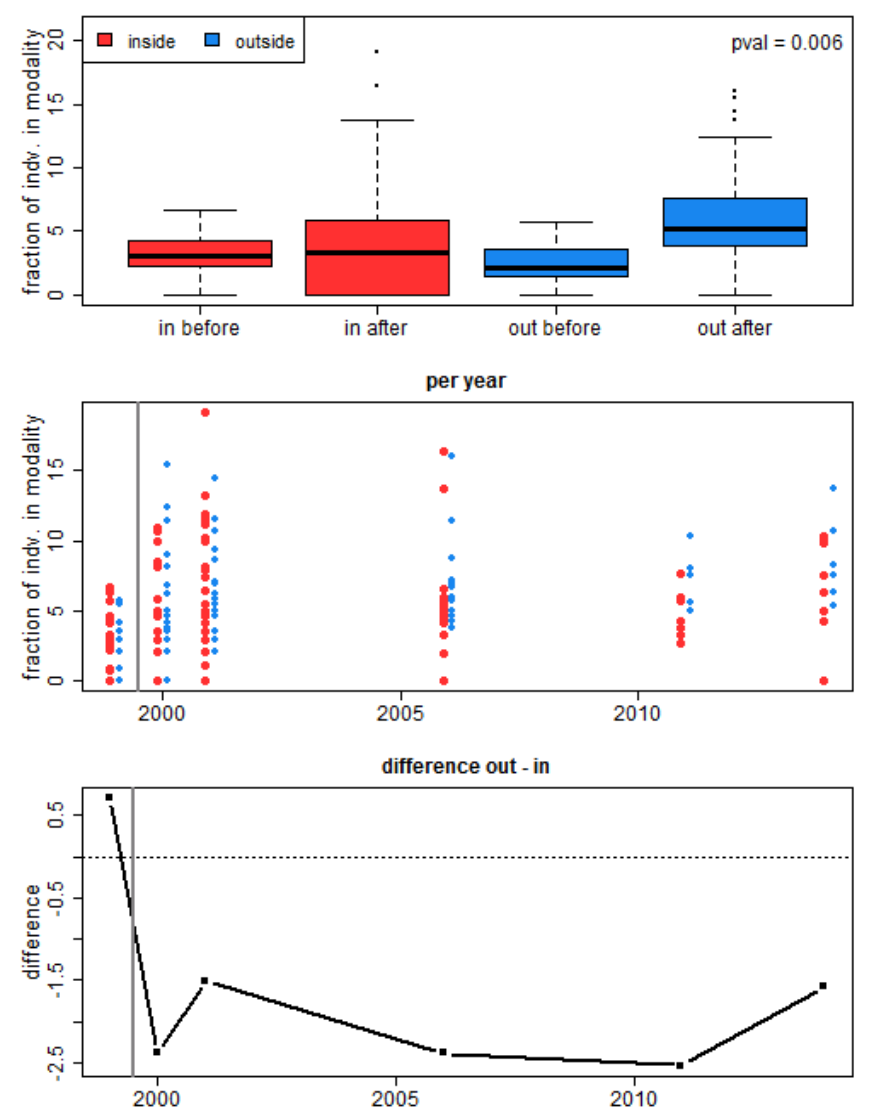

Figure 3-3 Distribution of modality 'epi/endo zoic/phytic' for inside and outside locations. Top panel boxplot of before-after for inside and outside area. Middle panel dotplot of inside and outside area per year. Lower panel mean difference between inside and outside area per year.

In Figure 3-3 the distribution of the modality 'Epi/edo zoic/phytic' within the trait Living habitat is shown before and after placement of the platform. As can be seen in the lower panel the difference in modality between inside and outside sampling locations occurs immediately after the placement of platform (i.e. in the year 2000) and the absolute difference between the zones remains more or less equally large in subsequent years.

Nine taxa within the modality 'Epi/endo zoic/phytic' (Living Habitat) were present in the dataset including taxa belonging to phylum Annelida, Arthropoda and Mollusca. Of these taxa only the Annelida Scoloplos aggregate and the Mollusca Saxicavella jeffreysi occur every year and in reasonable densities. The taxon Scoloplos aggregate seems to be the dominant taxon that drives the observed difference in development of the 'Epi/endo zoic/phytic' modality between the two areas. This taxon becomes more abundant outside the $500 \mathrm{~m}$ zone after placement of the platform (Figure 3-4). 

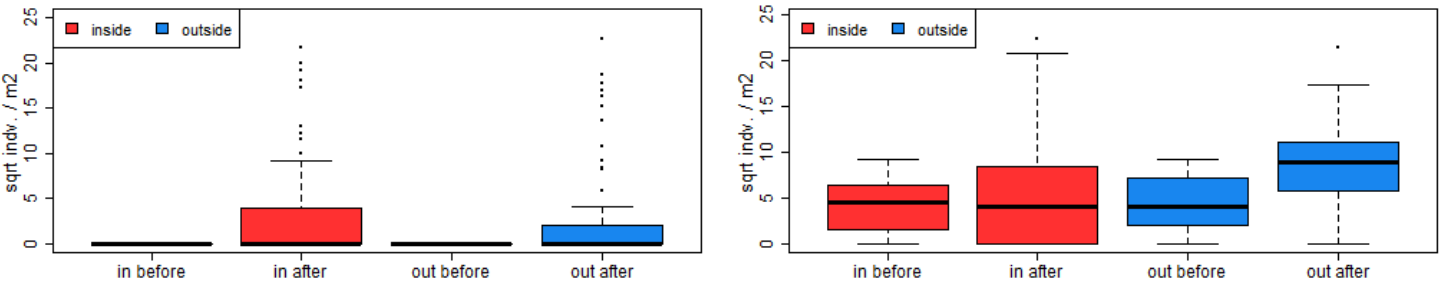

per year
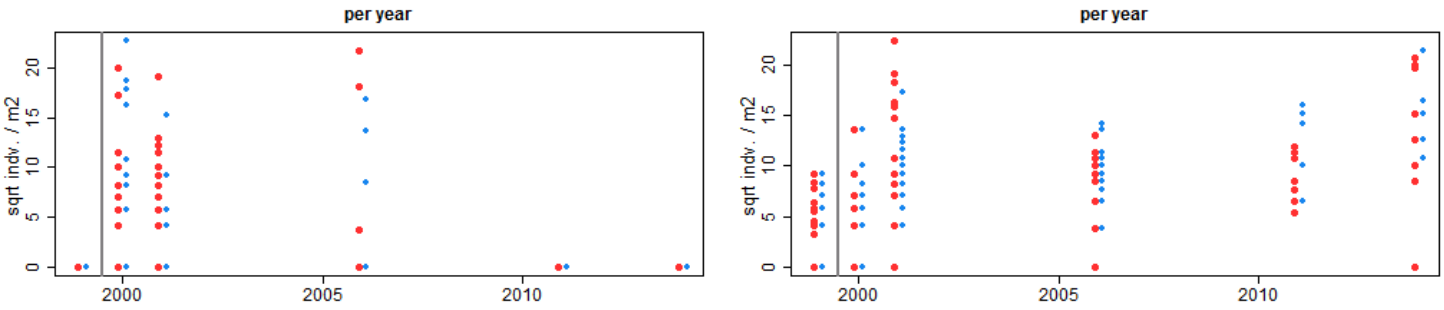

difference out - in
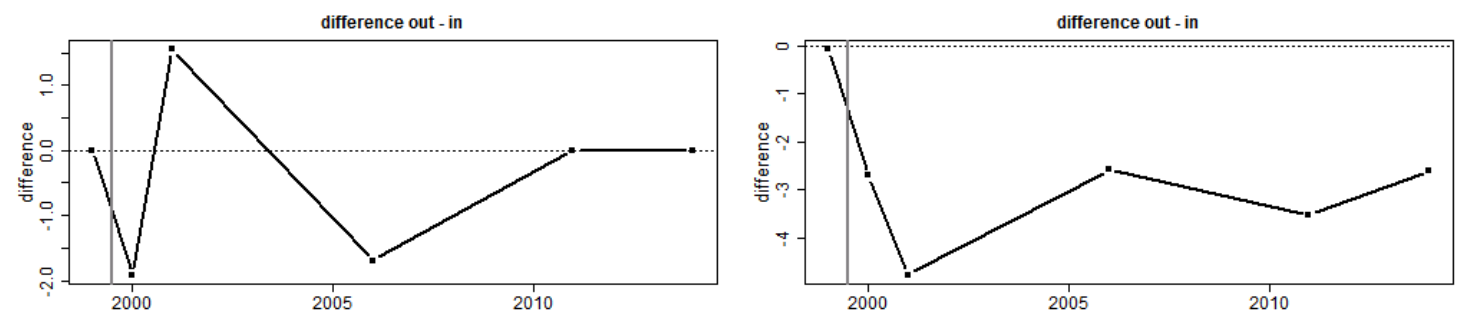

Figure 3-4 Development of the taxa Saxicavella jeffreysi (left) and Scoloplos aggregates (right) inside (not fished) and outside (fished) $500 \mathrm{~m}$ zone. Top panel; boxplot of before-after for the inside and outside areas, middle panel; dotplot of species densities inside and outside areas per year, lower panel; mean differences in species densities between inside and outside areas.

In Annex 6 an overview is given of the difference in mean modality densities for the inside and outside sampling group before placement of the platform (in year 1999), differences in development between the sample groups of all modalities and differences in trends in time for modalities expressed as ratios. Results are summarized in Table 3.2 and mean ratios of modalities per sample group and year are depicted in Figure 3-5.

Several modalities already differ significantly in 1999, before the platform is placed, see table 3.2. When analysing the development of modalities at intermediate time steps (before vs 2006, before vs 2011 and before vs 2014) it is notable that significant differences that do occur disappear in consecutive sampling events. In all cases densities are higher for the inside sampling group. These include species that belong to modalities that live on the sediment surface, are capable of swimming to some extent, are short lived and have no larval stage. Differences in developments in modalities are for most cases a result of an (larger) increase in trait density in the outside sampling group, see Annex 6 and Table 3.2. This includes modalities with species that are relative large, have a moderate life span, are able to swim and have no larval stage. An exception of this is the modality burrow (living habitat) that shows a larger increase in the inside sample group, especially in 2014 . 
Table 3.2 Modalities with a significant different development (after Bonferroni correction $\mathrm{p}$ values $<0.001$ ) in the inside sampling locations compared to the outside sampling locations. Four time periods were compared namely before (1999) - after (2000 till 2014), before (1999) - after (2006), before (1999) - after (2011) and before (1999) - after (2014), differences in mean densities for both sample groups in 1999 is also provided as well as significant different trends in ratios. Blank cells indicate no significant different development between zones. See annex 6 for results for all modalities. Developments (similar, increase, decrease) are indicated starting with the inside sample group followed by the outside sample group. Developments printed in bold are largest.

\begin{tabular}{|c|c|c|c|c|c|c|c|}
\hline Trait & Modality & 1999 & $\begin{array}{l}\text { Before - } \\
\text { after }\end{array}$ & $\begin{array}{l}\text { Before - } \\
2006\end{array}$ & $\begin{array}{l}\text { Before - } \\
2011\end{array}$ & $\begin{array}{l}\text { Before - } \\
2014\end{array}$ & Trend \\
\hline Size range & $101-200$ & & & & $\begin{array}{l}\text { increase / } \\
\text { increase }\end{array}$ & & \\
\hline Longevity & $<1$ & $\begin{array}{l}\text { higher } \\
\text { inside }\end{array}$ & & & & & \\
\hline $\begin{array}{l}\text { Sediment } \\
\text { position }\end{array}$ & Surface & $\begin{array}{l}\text { Higher } \\
\text { inside }\end{array}$ & & & & & \\
\hline $\begin{array}{l}\text { Larval } \\
\text { DevLoc }\end{array}$ & Direct & $\begin{array}{l}\text { higher } \\
\text { inside }\end{array}$ & $\begin{array}{l}\text { decrease / } \\
\text { increase }\end{array}$ & & & & \\
\hline $\begin{array}{l}\text { Living } \\
\text { habitat }\end{array}$ & Burrow & & & & & $\begin{array}{l}\text { increase / } \\
\text { increase }\end{array}$ & $\begin{array}{l}\text { increase / } \\
\text { increase }\end{array}$ \\
\hline Mobility & Swim & $\begin{array}{l}\text { higher } \\
\text { inside }\end{array}$ & $\begin{array}{l}\text { similar / } \\
\text { increase }\end{array}$ & $\begin{array}{l}\text { similar / } \\
\text { increase }\end{array}$ & & & \\
\hline
\end{tabular}



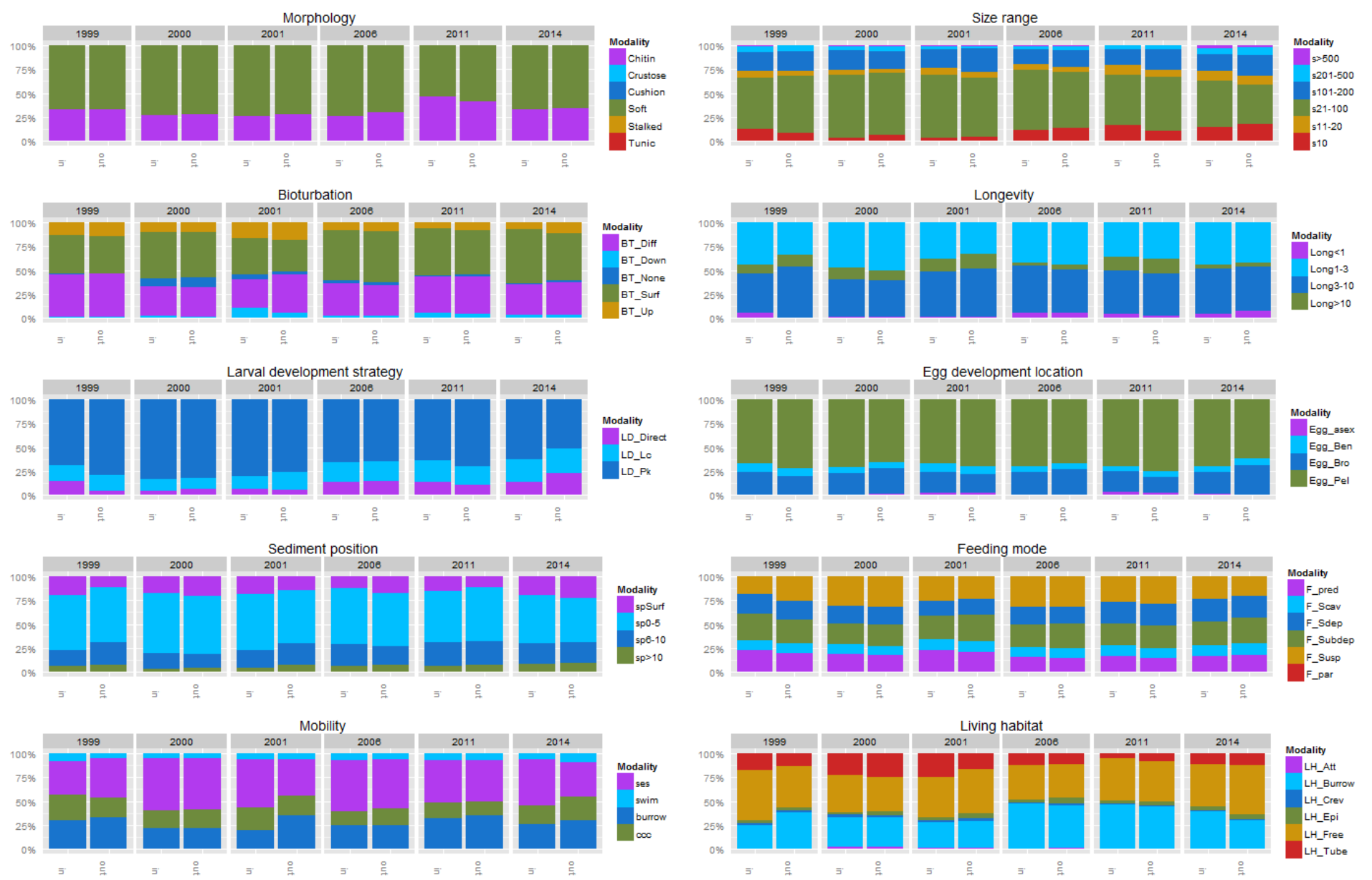

Figure 3-5 Mean modality composition per sampling year inside the $500 \mathrm{~m}$ zone ('in') and at a distance of $1000 \mathrm{~m}$ from platform ('out'). 


\section{Discussion}

Here, we studied a dataset of the benthic community in an area that was open for fisheries for many years before installation of a gas production platform, after which it was closed to fisheries. The closed area was hypothesised to function as a marine protected area (MPA), with the expectation that the benthic community would develop differently inside the closed area compared to the benthic community in the surrounding areas, due to the absence of the impact of fisheries, as has been shown for other areas (J ennings et al., 2001) and another exclusion zone of a gas platform (Duineveld et al., 2007). Differences in development might be linked to the impact of fisheries and the effects of the fisheries closure might provide an expectation for the effect of planned MPAs in comparable areas.

The exclusion of fishing was not the only change in that occurred in the closed area. The platform installation and subsequent drilling operations have also potentially impacted the seafloor. During drilling, mud mixed with process water is produced, which could lead to local mortality of benthos by burial. This mud deposition may also have led to local oxygen depletion. These additional effects of the platform installation on the benthos confound and cannot be disentangled of, the effects of the exclusion of the fishery, limiting our ability to link changes in benthos to the impact of fisheries and draw conclusions on the effectivity of MPAs.

The analyses were done on trait groups rather than by species abundances (Bolam and Eggleton, 2014), in order to analyse the effect of the exclusion of fisheries on the ecological functions and properties of the benthic community. The results indicate that less than $4 \%$ of the variation in trait groups and their corresponding modalities between the closed area and the surrounding fished area can be explained by fisheries. In terms of individual trait modalities, we find that only the modality 'Epi/endo zoic/phytic' showed a significant larger increase in time in the zone open for fishery compared to the zone closed for fishery when analysing before vs after (2000 - till 2014 combined). Going back to species level, we find that this is largely caused by the genus Scoloplos (Annelida), which are detritivores worms that might profit from the sediment disturbance caused by fishing.

When analysing the development of modalities at intermediate time steps (before vs 2006, before vs 2011 and before vs 2014) it was found that for modalities that show a significant different development between the fished and not fished sample group (1) differences did not last but disappeared in consecutive sampling events and (2) modalities have all except one increased more in areas closed to fishery. These include 'Size range - 101-200', 'Larval development location - direct', and 'Mobility - swim'. The only exception is the modality 'Living habitat - burrow', which has in 2014 increased more in the not fished sampling group. Of these modalities, 'Mobility - swim' might be linked to fisheries as these species have the potential to escape from approaching fishing gear and/or are able to rapidly recolonise fished areas. No modalities that have found to have a negative relationship with trawl disturbance in other studies, such as long lived, hard bodied and suspension feeding organisms (van Denderen et al., 2015b) have increased in the area from which fishing was excluded. Contrary to expectations, larger sized species have increased in samples taken in the fished area. It is however important to note that the trait 'size' relates to the maximum size for a particular genus. It is still possible that the individuals of these taxa in the samples were small. The increased occurrence of large species can also be because these particular species have other traits that compensate for the increased vulnerability incurred by their large size. It could be that they are all buried very deep in the sediment. A detailed analysis of such coupling between traits is beyond the scope of this analysis. That differences in the development of modalities between the fished and not fished sampling group did not last but disappeared over subsequent sampling events implies that a possible fishing effect is only temporal of nature and/or drilling activities reset an alternative development. Both effects cannot be disentangled from one another as stated before.

The hypotheses that long living immobile (bivalve) species could grow larger and/or become older in the exclusion zone as they are not disturbed or fished away by itself could not be tested. First the 
boxcorer is not suited to sample this species appropriate, furthermore size and age of captured shellfish was not measured.

The baseline, prior to the installation of the gas platform, is only a single year. This means that natural variation prior to the installation is not monitored and cannot be incorporated in the analysis. As a result the single year is considered as the true situation, making it particularly important in testing for developments in the benthic community over time. Any abnormal deviation in that year is regarded as being the normal situation. We found that differences between the inside and outside sampling group already existed before placement of the platform, with higher densities inside the future $500 \mathrm{~m}$ zone closed for fisheries. No explanation for this difference at the start of the monitoring could be found other than natural occurring spatial variation in the area. A second problematic aspect of the dataset used is a decrease of sampling effort over time. This makes it more difficult to detect differences between sampling groups in later years. It has been stated that the large proportion of relative shortliving species and the relative scarcity of vulnerable larger species in boxcorer samples makes this device less suited for adequate sampling of the latter (Bergman et al., 2015, Duineveld et al., 2007). Effects of a fishing ban on benthic communities were more expressed in samples collected with a Triple-D device, sampling a larger area, compared to samples that were taken with a boxcorer (Bergman et al., 2015, Duineveld et al., 2007).

A possible explanation for the absence of differences in the benthic community could be that the area around the platform is too small to sustain a stable and diverse benthic community. Natural disturbance of the seafloor caused by currents (Aldridge et al., 2015) could homogenise the inside area with the outside area. It has been found that natural disturbances have effects on the benthic community comparable to disturbance by trawling, tempering the effect of trawl disturbance (van Denderen et al., 2015b). Sediment displacements have been found during sampling after a storm in the area (personal observations of author). 


\section{Conclusions and recommendations}

The assignment was to look for datasets collected for a range of purposes, that could be used to analyse the effect of fisheries closures. The dataset analysed here was collected to assess direct impact of the construction and activities related to the gas platform. We analysed the data for effects of the fisheries closure in the 500 m safety zone.

We found that species living on top of, or in the top layer of, the sediment increased significantly over time in the fished area, compared to the closed area and found some none lasting differences at intermediate time steps. This is less than a priori expected, both in magnitude and in number of significant effects. Other studies of changes in biological trait composition of benthos in response to cessation of fishing find more and stronger effects.

We consider it likely that this result is a consequence of the poor data quality in relation to the question asked here. There are many problems with this data set, including:

- Monitoring not designed for this purpose

- Sampling device not suited to appropriately sample species expected to show the largest effect on the long term.

- $\quad$ Length and age of species is not determined

- Only a single baseline year

- $\quad$ Various events occurred over the time series potentially affecting the benthic community as well.

- $\quad$ Limited information on actual fishing pressure prior to installation and over the time series in the outside area.

Our analysis method is one of many which can be used in detecting effects of fisheries closures. Various other methods might be tried to look at the same data in a slightly different manner, and would answer the same question slightly differently. However, the power of all these method will be limited due to the described data limitations. Therefore, we advise not to further investigate and analyse this Wintershall benthos dataset in the context of fisheries closures.

Our advice is to design hypothesis-driven monitoring if any further study on the effect of fisheries closures in the sandy southern North Sea is required. There are $>100$ platforms with a $500 \mathrm{~m}$ safety zone in the Dutch EEZ that are present for decades, these could be used in such a monitoring study. Also the two Dutch offshore wind parks, offshore Wind park Egmond aan Zee (OWEZ) and Prinses Amalia Wind Park (PAWP) are currently in place for about 10 years allowing species to grow large / become old. Prior to such a study, the actual fishing pressure in the reference locations should be analysed, such that a gradient of fishing pressure could be incorporated in the analysis. 


\section{Quality Assurance}

I MARES utilises an ISO 9001:2008 certified quality management system (certificate number: 124296-2012-AQ-NLD-RvA). This certificate is valid until 15 December 2015. The organisation has been certified since 27 February 2001. The certification was issued by DNV Certification B.V. Furthermore, the chemical laboratory of the Fish Division has NEN-EN-ISO/IEC 17025:2005 accreditation for test laboratories with number L097. This accreditation is valid until 1th of April 2017 and was first issued on 27 March 1997. Accreditation was granted by the Council for Accreditation. The scope can be found at the website of the Council for Accreditation (www.rva.nl). 


\section{References}

Aldridge, J. N., Parker, E. R., Bricheno, L. M., Green, S. L., \& van der Molen, J. 2015. Assessment of the physical disturbance of the northern European Continental shelf seabed by waves and currents. Continental Shelf Research, 108, 121-140.

Beare, D., Rijnsdorp, A. D., Blaesberg, M., Damm, U., Egekvist, J., Fock, H., Kloppmann, M., et al. 2013. Evaluating the effect of fishery closures: Lessons learnt from the Plaice Box. Journal of Sea Research, 84: 49-60.

Bergman, M. J. N., Ubels, S. M., Duineveld, G. C. A., and Meesters, E. W. G. 2015. Effects of a 5-year trawling ban on the local benthic community in a wind farm in the Dutch coastal zone. ICES Journal of Marine Science, 72: 962-972.

Bergman, M. J. N., and van Santbrink, J. W. 2000. Mortality in megafaunal benthic populations caused by trawl fisheries on the Dutch continental shelf in the North Sea in 1994. ICES J. Mar. Sci., 57: 13211331.

Bolam, S. G., Coggan, R. C., Eggieton, J., Diesing, M., and Stephens, D. 2014. Sensitivity of macrobenthic secondary production to trawling in the English sector of the Greater North Sea: A biological trait approach. Journal of Sea Research, 85: 162-177.

Bolam, S. G., and Eggleton, J. D. 2014. Macrofaunal production and biological traits: Spatial relationships along the UK continental shelf. Journal of Sea Research, 88: 47-58.

Depestele, J., Ivanović, A., Degrendele, K., Esmaeili, M., Polet, H., Roche, M., Summerbell, K., et al. 2015. Measuring and assessing the physical impact of beam trawling. ICES Journal of Marine Science: Journal du Conseil.

Glorius, S. T., van der Weide, B. E., and Kaag, N. H. B. M. 2015. Post drill survey A6-A6 2014. IMARES report C046.15. $41 \mathrm{pp}$.

Jennings, S., Pinnegar, J. K., Polunin, N. V. C., and Warr, K. J. 2001. Impacts of trawling disturbance on the trophic structure of benthic invertebrate communities. Marine Ecology Progress Series, 213: 127142.

Lindeboom, H. J., Kouwenhoven, H. J., Bergman, M. J. N., Bouma, S., Brasseur, S., Daan, R., Fijn, R. C., et al. 2011. Short-term ecological effects of an offshore wind farm in the Dutch coastal zone; a compilation. Environmental Research Letters, 6: 035101.

Oksanen, J., Blanchet, F. G., Kindt, R., Legendre, P., Minchin, P. R., O'Hara, R. B., Simpson, G. L., et al. 2013. 2013. vegan: Community Ecology Package. R package version 2.0-7. Available at http://CRAN.R-project.org/package=vegan.

Pearson, T. H., and Rosenberg, R. 1978. Macrobenthic successions in relation to organic enrichment and pollution of the marine environment. Oceanography and marine biology: an annual review, 16: 229311.

Rosenberg, R. 1995. Benthic marine fauna structured by hydrodynamic processes and food availability. Netherlands J ournal of Sea Research, 34: 303-317.

Thrush, S. F., and Whitlatch, R. B. 2001. Recovery Dynamics in Benthic Communities: Balancing Detail with Simplification. In Ecological Comparisons of Sedimentary Shores, pp. 297-316. Springer Berlin Heidelberg.

Tillin, H. M., Hiddink, J. G., Jennings, S., and Kaiser, M. J. 2006. Chronic bottom trawling alters the functional composition of benthic invertebrate communities on a sea-basin scale. Marine Ecology Progress Series, 318: 31-45

van Denderen, P. D., Bolam, S. G., Hiddink, J. G., Jennings, S., Kenny, A., Rijnsdorp, A. D., and van Kooten, T. 2015a. Similar effects of bottom trawling and natural disturbance on composition and function of benthic communities across habitats. Marine Ecology Progress Series, 541: 31-43.

van Denderen, P. D., Hintzen, N. T., Rijnsdorp, A. D., Ruardij, P., and van Kooten, T. 2014. Habitat-specific effects of fishing disturbance on benthic species richness in marine soft sediments. Ecosystems, 17: 1216-1226.

van Denderen, P. D., Hintzen, N. T., van Kooten, T., and Rijnsdorp, A. D. 2015b. Temporal aggregation of bottom trawling and its implication for the impact on the benthic ecosystem. ICES Journal of Marine Science: Journal du Conseil, 72: 952-961.

van Denderen, P. D., Rijnsdorp, A. D., and van Kooten, T. 2016. Using marine reserves to manage impact of bottom trawl fisheries requires consideration of benthic food-web interactions. Ecological Applications: n/a-n/a. 
Van der Reijden, KJ, MAM Machiels, BK Trapman and ML Kraan, 2016. Monitoring cod catches of the Dutch demersal fleet in 2014; Investigating the effects of season and fishing gear on cod landings. Wageningen, I MARES Wageningen UR (University \& Research centre), I MARES report. 


\section{Justification}

Report C121/16

Project Number: 4318100029

The scientific quality of this report has been peer reviewed by the a colleague scientist and the management team of IMARES.

Approved: $\quad$ Oscar Bos

Researcher

Signature:

Date:

21-12-2016

Approved: $\quad$ Drs. J. Asjes

Integration Manager

Signature:

Date:

21-12-2016 


\section{Annex 1 Stations sampled in period 1999 - 2014}

Table 1.

Number of samples that were analysed per station and sampling year.

\begin{tabular}{|c|c|c|c|c|c|c|c|}
\hline Distance (m) & $\begin{array}{l}\text { Angle } \\
\text { (degr) }\end{array}$ & 1999 & 2000 & 2001 & 2006 & 2011 & 2014 \\
\hline 0 & 0 & 10 & & & & & \\
\hline 125 & 135 & 5 & 10 & 10 & 3 & 1 & 1 \\
\hline 125 & 225 & 6 & 5 & 5 & 3 & 1 & 1 \\
\hline 125 & 315 & 5 & 5 & 5 & 3 & 1 & 1 \\
\hline 125 & 45 & 5 & 5 & 5 & 3 & 1 & 2 \\
\hline 250 & 135 & 5 & 5 & 5 & 3 & & 1 \\
\hline 250 & 225 & 6 & 5 & 5 & 3 & 1 & 1 \\
\hline 250 & 315 & 4 & 5 & 5 & 3 & 1 & 1 \\
\hline 250 & 45 & 5 & 5 & 5 & 3 & 1 & 2 \\
\hline 500 & 135 & 5 & 5 & 5 & 3 & & 1 \\
\hline 500 & 225 & 5 & 5 & 5 & 3 & 1 & 1 \\
\hline 500 & 315 & 5 & 5 & 5 & 3 & 1 & 1 \\
\hline 500 & 45 & 4 & 5 & 5 & 3 & 1 & 2 \\
\hline 1000 & 135 & 5 & 5 & 5 & 3 & 1 & 1 \\
\hline 1000 & 180 & 5 & 5 & 5 & 3 & 1 & 1 \\
\hline 1000 & 225 & 5 & 5 & 5 & 3 & 1 & 1 \\
\hline 1000 & 315 & & & & & 1 & 1 \\
\hline 1000 & 45 & 5 & 5 & 5 & 3 & 1 & 1 \\
\hline 1000 & 90 & 5 & 5 & 5 & 3 & & 1 \\
\hline 2000 & 135 & 5 & 5 & 5 & 3 & 1 & 1 \\
\hline 2000 & 180 & 5 & 5 & 5 & 3 & 1 & 1 \\
\hline 2000 & 225 & & & & & 1 & 1 \\
\hline 2000 & 315 & & & & & 1 & 1 \\
\hline 2000 & 45 & & & & & 1 & 1 \\
\hline 2000 & 90 & 5 & 5 & 5 & 3 & 1 & 1 \\
\hline \multicolumn{8}{|c|}{ REFERENCE } \\
\hline 4000 & 135 & 5 & 5 & 5 & 3 & 1 & 1 \\
\hline 6000 & 290 & 10 & 10 & 10 & 3 & & \\
\hline 10,000 & 0 & & & & & 1 & 1 \\
\hline 10,000 & 180 & & & & & 1 & 1 \\
\hline 10,000 & 290 & & & & & 1 & 1 \\
\hline
\end{tabular}




\section{Annex 2 Traits and categories}

Table 1. Traits and trait categories. The labelling of each trait category during numerical analyses and for presentation within figures and tables is given in brackets. All modalities signed with three asterisks (***) had an occurrence of less than $10 \%$ in the samples. These modalities were not included in the redundancy analysis.

\begin{tabular}{|c|c|c|}
\hline Trait + code & Modalities & Trait Definition and functional significance \\
\hline Size range (s) & $\begin{array}{l}\leq 10(s 10) \\
11-20(s 11-20) \\
21-100(s 21-100) \\
101-200(s 101-200) \\
200-500(s 200-500) \\
>500(s>500)\end{array}$ & $\begin{array}{l}\text { In mm. Maximum recorded size of adult (as individuals or } \\
\text { colonies). Implications for the movement of organic matter } \\
\text { within the benthic system as large organisms hold organic } \\
\text { matter (low turnover) within the system relative to small- } \\
\text { bodied species (high turnover) (Pearson and Rosenberg, } \\
\text { 1978). }\end{array}$ \\
\hline Morphology & $\begin{array}{l}\text { Soft (soft) } \\
\text { Tunic (Tunic) } \quad * * * \\
\text { Exoskeleton (chitin/calcium carbonate) } \\
\text { (Chitin) } \\
\text { Crustose (Crustose) }\end{array}$ & External characteristics of the taxon. \\
\hline Longevity (Long) & $\begin{array}{l}<1(\text { Long }<1) \\
1-3(\text { Long } 1-3) \\
4-10(\text { Long3-10) } \\
>10(\text { Long }>10)\end{array}$ & $\begin{array}{l}\text { Maximum reported life span of the adult stage. Indicates } \\
\text { the relative investment of energy in somatic rather than } \\
\text { reproductive growth and the relative age of sexual maturity, } \\
\text { i.e. a proxy for relative } r \text { - and k- strategy (Pearson and } \\
\text { Rosenberg, 1978) }\end{array}$ \\
\hline $\begin{array}{l}\text { Larval development } \\
\text { strategy } \\
\text { (LD) }\end{array}$ & $\begin{array}{l}\text { Planktotrophic (LD_Pk) } \\
\text { Lecithotrophic (LD_Lc) } \\
\text { Direct (LD_Direct) }\end{array}$ & $\begin{array}{l}\text { Indicates the potential for dispersal of the larval stage prior } \\
\text { to settlement from direct (no larval stage), lecithotrophic } \\
\text { (larvae with yolk sac, pelagic for short periods) to } \\
\text { planktotrophic (larvae feed and grow in water column, } \\
\text { generally pelagic for several weeks). Affects ability to } \\
\text { recover from disturbance with planktonic recruitment } \\
\text { affording potentially faster recolonisation than lecithotrophic } \\
\text { and direct development (Thrush and Whitlatch, 2001). }\end{array}$ \\
\hline $\begin{array}{l}\text { Egg development } \\
\text { location } \\
\text { (Egg) }\end{array}$ & $\begin{array}{l}\text { Asexual/fragmentation (Egg_asex) } \\
\text { Eggs - pelagic (Egg_Pel) } \\
\text { Eggs - benthic (Egg_Ben) } \\
\text { Eggs - brooded (Egg_Bro) }\end{array}$ & $\begin{array}{l}\text { Indicates dispersal via the egg stage and the potential } \\
\text { susceptibility of eggs to damage from fishing. Benthic eggs } \\
\text { are generally more concentrated over smaller areas. } \\
\text { Asexual reproduction allows the potential to increase } \\
\text { numbers rapidly, particularly following disturbance. }\end{array}$ \\
\hline $\begin{array}{l}\text { Living habit } \\
\text { (LH) }\end{array}$ & $\begin{array}{l}\text { Tube-dwelling (LH_Tube) } \\
\text { Burrow-dwelling (LH_Burrow) } \\
\text { Free living (LH_Free) } \\
\text { Crevice/under stone (LH_Crev) } \\
\text { Epi/endo zoic/phytic (LH_Epi) } \\
\text { Attached to bed (LH_Att) }\end{array}$ & $\begin{array}{l}\text { Indicates potential for the adult stage to evade, or to be } \\
\text { exposed to, physical disturbance. }\end{array}$ \\
\hline $\begin{array}{l}\text { Sediment position } \\
\text { (SP) }\end{array}$ & $\begin{array}{l}\text { Surface (spSurf) } \\
0-5 \mathrm{~cm}(\mathrm{sp} 0-5) \\
5-10 \mathrm{~cm}(\mathrm{sp} 6-10) \\
>10 \mathrm{~cm}(\mathrm{sp}>10)\end{array}$ & $\begin{array}{l}\text { Typical living position in sediment profile. Organisms } \\
\text { occupying shallower positions in the sediment are more } \\
\text { likely to contact trawl gear than those living deeper. } \\
\text { Sediment position also has implications for the effect of the } \\
\text { organism to affect sediment-water nutrient and/or oxygen } \\
\text { exchange. }\end{array}$ \\
\hline $\begin{array}{l}\text { Feeding mode } \\
\text { (F) }\end{array}$ & $\begin{array}{l}\text { Suspension (F_Susp) } \\
\text { Surface deposit (F_Sdep) } \\
\text { Subsurface deposit (F_Subdep) } \\
\text { Scavenger (F_Scav) } \\
\text { Predator (F_pred) } \\
\text { Parasite (F_par) } * * * \\
\end{array}$ & $\begin{array}{l}\text { Feeding mode has important implications for the potential } \\
\text { for transfer of carbon between the sediment and water and } \\
\text { within the sediment matrix. Feeding mode also has } \\
\text { important repercussions for many biogeochemical processes } \\
\text { (Rosenberg, 1995). }\end{array}$ \\
\hline $\begin{array}{l}\text { Mobility } \\
\text { (M) }\end{array}$ & $\begin{array}{l}\text { Sessile (M_Sess) } \\
\text { Swim (M_Swim) } \\
\text { Burrow (M_Burrow) } \\
\text { Crawl (M_Crawl) }\end{array}$ & $\begin{array}{l}\text { Adults of faster moving species are more likely to evade } \\
\text { capture by trawl gear than slow-moving or sessile } \\
\text { individuals. Mobility also affects the ability for adult } \\
\text { recolonisation of disturbed areas. }\end{array}$ \\
\hline $\begin{array}{l}\text { Bioturbation } \\
\text { (BT) }\end{array}$ & $\begin{array}{l}\text { Diffusive mixer (BT_Diff) } \\
\text { Surface deposition (BT_Surf) } \\
\text { Upward conveyor (BT_Up) } \\
\text { Downw. conv.(BT_Down) } \\
\text { None (BT_None) }\end{array}$ & $\begin{array}{l}\text { Describes the ability of the organism to rework the } \\
\text { sediments. Can either be upward, downward, onto the } \\
\text { sediment or mixing of the sedimentary matrix. Bioturbation } \\
\text { mode has important implications for sediment-water } \\
\text { exchange and sediment biogeochemical properties. }\end{array}$ \\
\hline
\end{tabular}




\section{Annex 3 Linking species to trait modalities}

Table 1.

\begin{tabular}{|c|c|c|c|c|c|c|}
\hline Spec code & Phylum & Familie & Genus & Species & Action & $\begin{array}{l}\text { Linkage Trait } \\
\text { database }\end{array}$ \\
\hline OXYDFLEX & Annelida & Hesionidae & Oxydromus & flexuosus & $\begin{array}{l}\text { Synonym name } \\
\text { used }\end{array}$ & Ophiodromus \\
\hline HEDIDIVE & Annelida & Nereididae & Hediste & diversicolor & $\begin{array}{l}\text { Synonym name } \\
\text { used }\end{array}$ & Nereis \\
\hline NEREDNSP & Annelida & Nereididae & NEREI DINAE & & Trait family used & Nereididae \\
\hline ETEONISP & Annelida & Phyllodocidae & ETEONINAE & & Trait family used & Phyllodocidae \\
\hline BYLGSARS & Annelida & Polynoidae & Bylgides & sarsi & $\begin{array}{l}\text { Synonym name } \\
\text { used }\end{array}$ & Antinoella \\
\hline POLNSPEC & Annelida & Polynoidae & POLYNOINAE & & Trait family used & Polynoidae \\
\hline AUROBANY & Annelida & Spionidae & Aurospio & banyulensis & $\begin{array}{l}\text { Synonym name } \\
\text { used }\end{array}$ & Prionospio \\
\hline DIPDCOEC & Annelida & Spionidae & Dipolydora & coeca & $\begin{array}{l}\text { Synonym name } \\
\text { used }\end{array}$ & Polydora \\
\hline PAREHEBE & Annelida & Syllidae & Parexogone & hebes & $\begin{array}{l}\text { Synonym name } \\
\text { used }\end{array}$ & Exogone \\
\hline SABELISP & Annelida & & SABELLIDA & & Trait family used & Sabellidae \\
\hline POLYCHAE & Annelida & & POLYCHAETA & & Spelling & Polychaeta \\
\hline NOTTSWAM & Arthropoda & Atylidae & Nototropis & swammerdamei & $\begin{array}{l}\text { assumed similar } \\
\text { with }\end{array}$ & Gammarus \\
\hline ATYLIDSP & Arthropoda & Atylidae & Atylidae & & $\begin{array}{l}\text { assumed similar } \\
\text { with }\end{array}$ & Gammarus \\
\hline PESTTYRR & Arthropoda & Callianassidae & Pestarella & tyrrhena & Trait family used & Callianassa \\
\hline CAPRELSP & Arthropoda & Caprellidae & Caprellidae & & Trait family used & Caprella \\
\hline CORYSTSP & Arthropoda & Corystidae & Corystidae & & Trait family used & Corystes \\
\hline HYPEGALB & Arthropoda & Hyperiidae & Hyperia & galba & Trait family used & Hyperiidae \\
\hline TRYSNANA & Arthropoda & Lysianassidae & Tryphosa & nana & $\begin{array}{l}\text { Synonym name } \\
\text { used }\end{array}$ & Anonyx \\
\hline ERYTELEG & Arthropoda & Mysidae & Erythrops & elegans & Trait family used & Mysidae \\
\hline HEMMABYS & Arthropoda & Mysidae & Hemimysis & abyssicola & Trait family used & Mysidae \\
\hline HEMMLAMO & Arthropoda & Mysidae & Hemimysis & lamornae & Trait family used & Mysidae \\
\hline MYSDASP & Arthropoda & Mysidae & Mysidacea & spp. & Trait family used & Mysidae \\
\hline OEDISPEC & Arthropoda & Oedicerotidae & Oedicerotidae & spp. & $\begin{array}{l}\text { Added to trait } \\
\text { database }\end{array}$ & Oedicerotidae \\
\hline NECOPUBE & Arthropoda & Polybiidae & Necora & puber & $\begin{array}{l}\text { Synonym name } \\
\text { used }\end{array}$ & Liocarcinus \\
\hline STENOTSP & Arthropoda & Stenothoidae & Stenothoidae & & $\begin{array}{l}\text { Added to trait } \\
\text { database }\end{array}$ & Stenothoidae \\
\hline CARIDESP & Arthropoda & & CARIDEA & & Trait order used & DECAPODA \\
\hline MYSIDASP & Arthropoda & & MYSIDA & & Trait family used & Mysidae \\
\hline PAGURISP & Arthropoda & & PAGUROIDEA & & Trait order used & DECAPODA \\
\hline SAXIJFSI & Mollusca & Hiatellidae & Saxicavella & jeffreysi & Trait family used & Hiatellidae \\
\hline PROPTURR & Mollusca & Mangeliidae & Propebela & turricula & $\begin{array}{l}\text { Synonym name } \\
\text { used }\end{array}$ & Mangelia \\
\hline ENNUTENU & Mollusca & Nuculidae & Ennucula & tenuis & $\begin{array}{l}\text { Synonym name } \\
\text { used }\end{array}$ & Nucula \\
\hline NUCULISP & Mollusca & Nuculidae & NUCULIDAE & & Spelling & Nuculidae \\
\hline MIMAVARI & Mollusca & Pectinidae & Mimachlamys & varia & $\begin{array}{l}\text { Synonym name } \\
\text { used }\end{array}$ & Chlamys \\
\hline PHILINID & Mollusca & Philinidae & Philinidae & & $\begin{array}{l}\text { Synonym name } \\
\text { used }\end{array}$ & Philine \\
\hline PYRASPEC & Mollusca & Pyramidellidae & Pyramidellidae & spp. & $\begin{array}{l}\text { Added to trait } \\
\text { database }\end{array}$ & Pyramidellidae \\
\hline
\end{tabular}

List of actions taken for species that could not directly be linked to trait modalities. 


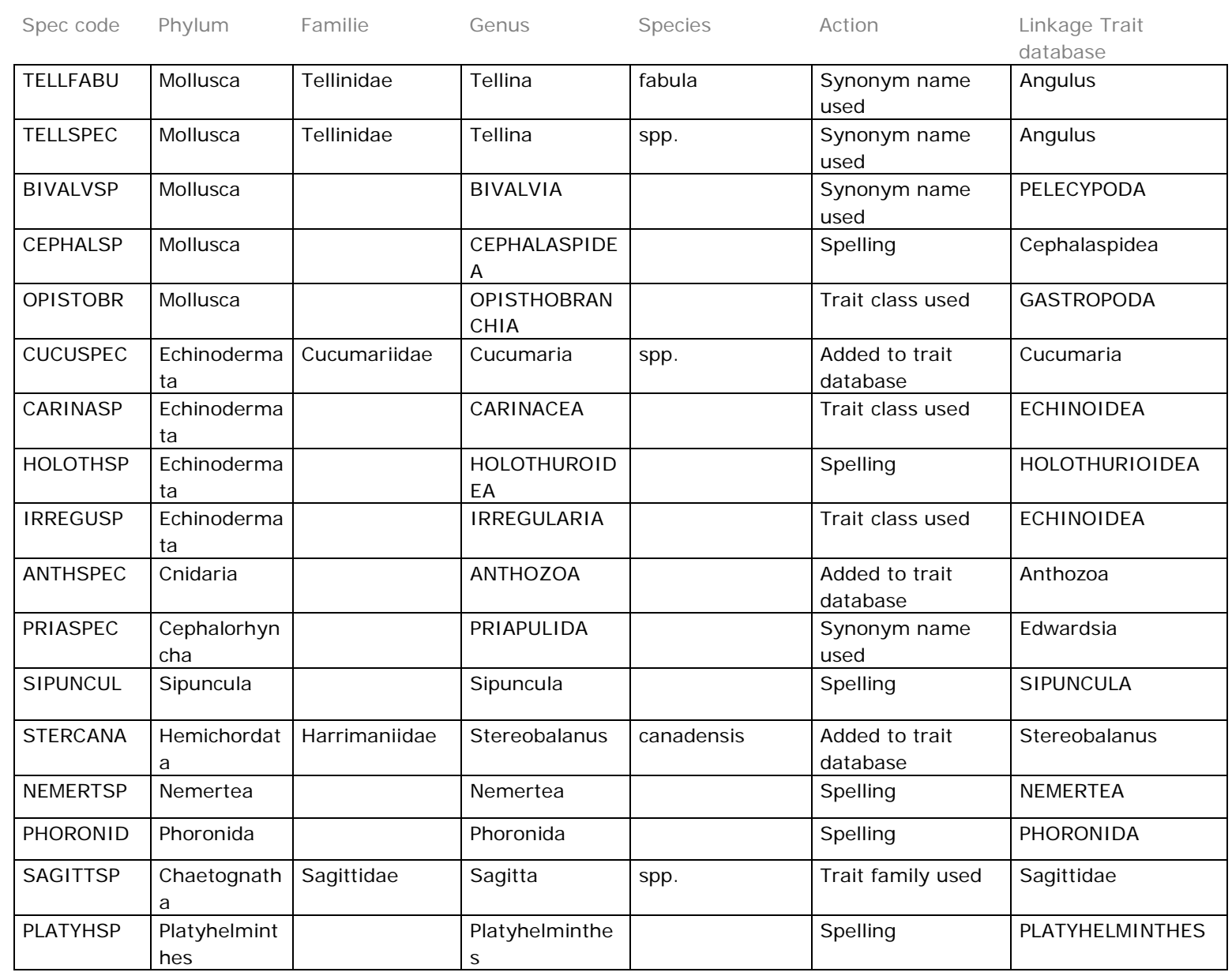




\section{Annex 4 Mean amount of species per phylum and year}

Table A4.1. Mean number of species per sample per year and per phylum for most dominant phyla.

Jaar

\begin{tabular}{|c|c|c|c|c|c|c|c|c|c|}
\hline & 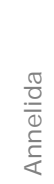 & $\begin{array}{l}\frac{0}{0} \\
\frac{0}{0} \\
\frac{0}{2} \\
\frac{1}{4} \\
\frac{1}{4}\end{array}$ & 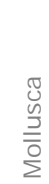 & 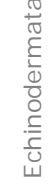 & $\begin{array}{l}\frac{\pi}{\frac{\pi}{\pi}} \\
\frac{\pi}{0} \\
\frac{0}{\tilde{L}}\end{array}$ & & $\begin{array}{l}\frac{\pi}{3} \\
\frac{\mathrm{C}}{5} \\
\frac{0}{n} \\
\end{array}$ & 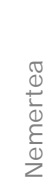 & $\begin{array}{l}\frac{\pi}{0} \\
\frac{0}{\tau} \\
\frac{0}{0} \\
\frac{1}{2}\end{array}$ \\
\hline 1999 & 10 & 1.9 & 2.9 & 1.6 & 0.4 & 0.1 & 0.0 & 0.5 & 0.1 \\
\hline 2000 & 11 & 1.4 & 3.8 & 1.8 & 0.7 & 0.2 & 0.0 & 0.5 & 1.0 \\
\hline 2001 & 11 & 1.4 & 3.5 & 1.6 & 1.1 & 0.2 & 0.0 & 0.7 & 0.8 \\
\hline 2006 & 11 & 3.8 & 3.6 & 1.1 & 0.3 & 0.8 & 0.8 & 0.6 & 0.7 \\
\hline 2011 & 15 & 5.0 & 7.0 & 3.3 & 1.2 & 0.0 & 0.0 & 0.5 & 0.7 \\
\hline 2014 & 17 & 7.2 & 7.6 & 3.3 & 0.7 & 0.1 & 0.4 & 0.5 & 0.6 \\
\hline
\end{tabular}

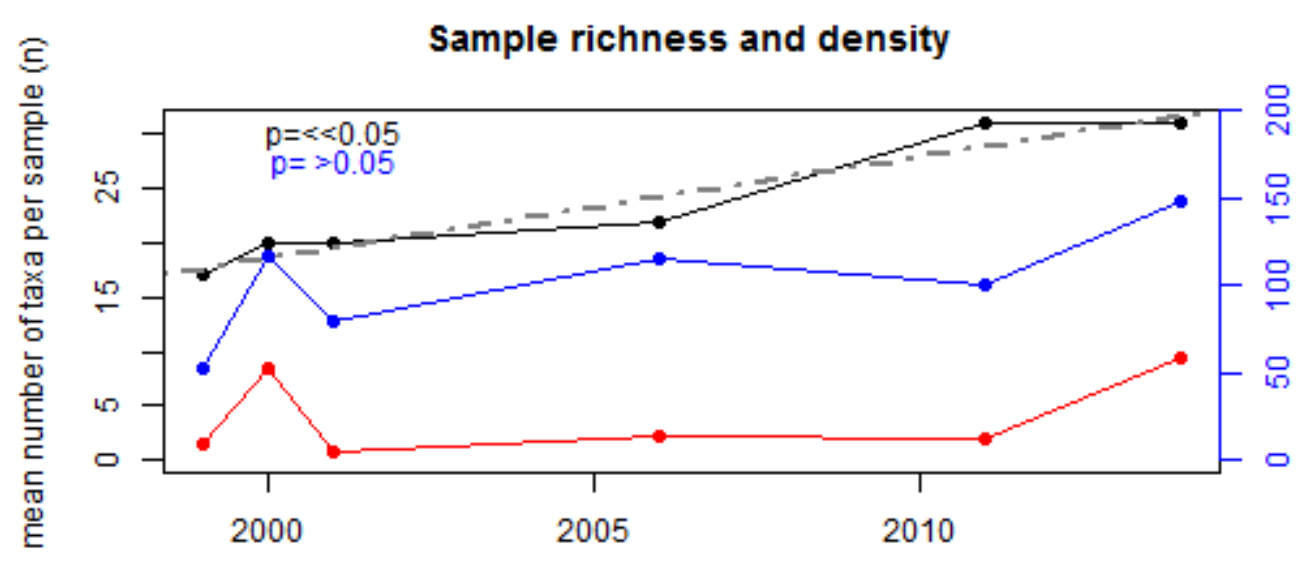

- mean richness p.sample

mean density p.sample

mean dens. Spiophanes bombyx p.samples

Figure A4.1. Development in mean number of species and mean density per sample and year. 


\section{Annex 5 Orientation centroids per year}

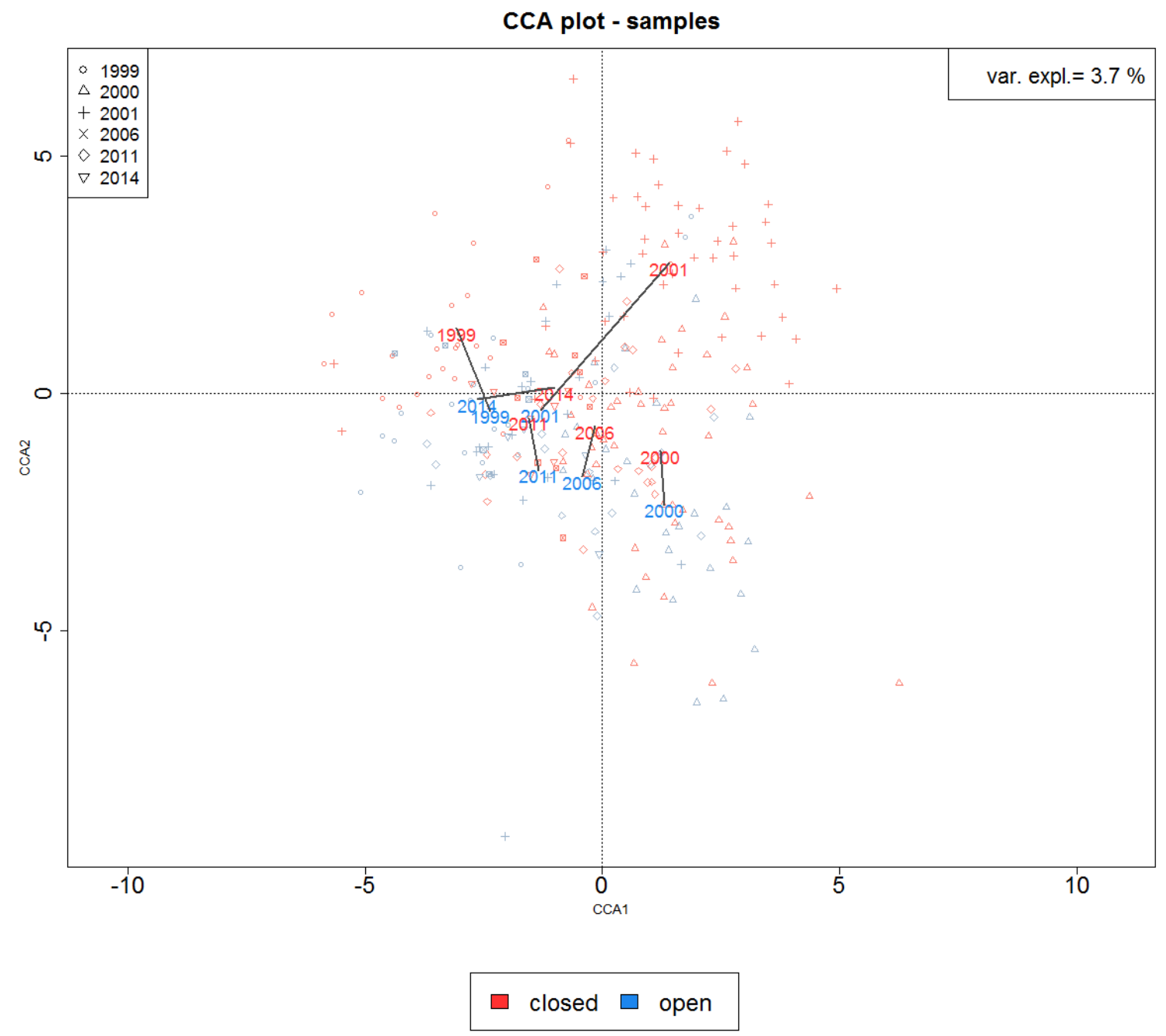

Figure A5.1. Constrained correspondence analysis orientation plot of the trait modalities with indication of centroids per year. Modalities are 30 fold magnified over the CCA1 and CCA2 axis. Only the 20 modalities that show largest variation between the zones (and times) are shown. Influence of time $(p=0.001)$, influence of zone $(p=0.19)$. 


\section{Annex 6 Development of significant modalities}

Table A6.1.

First two coloms show trait and modality. Third and fourt columns show test restults of mean difference (anova) between inside and outside $500 \mathrm{~m}$. sampling

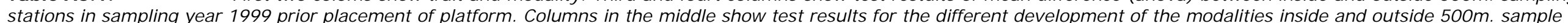

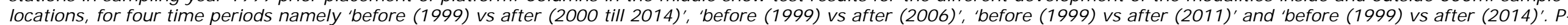

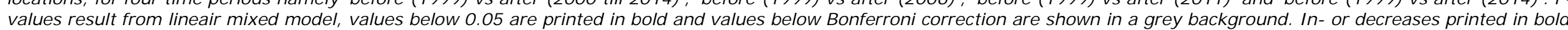

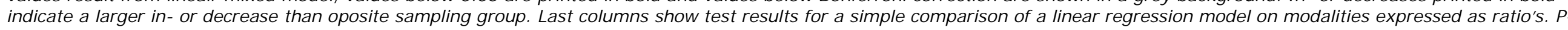
values below 0.05 are printed in bold and values below Bonferroni correction are shown in a grey background.

\begin{tabular}{|c|c|c|c|c|c|c|c|c|c|c|c|c|c|c|c|c|c|}
\hline \multirow[b]{2}{*}{ Trait } & \multirow[b]{2}{*}{$\begin{array}{l}\text { Modalit } \\
y\end{array}$} & \multicolumn{2}{|c|}{ Situation 1999} & \multicolumn{3}{|c|}{$\begin{array}{l}\text { Before - after ( } 2000 \text { - } \\
\text { 2014) }\end{array}$} & \multicolumn{3}{|c|}{ Before - after (2006) } & \multicolumn{3}{|c|}{ Before - after (2011) } & \multicolumn{3}{|c|}{ Before - after ( 2014) } & \multicolumn{2}{|c|}{ Trend ratio } \\
\hline & & pvalue & Inside & pvalue & inside & outside & pvalue & inside & outside & pvalue & inside & $\begin{array}{l}\text { outsid } \\
\text { e }\end{array}$ & pvalue & inside & $\begin{array}{l}\text { outsid } \\
\text { e }\end{array}$ & pvalue & Inside \\
\hline \multirow[t]{6}{*}{ SizeRange } & s10 & 0.024 & higher & 0.014 & decrease & increase & 0.070 & & & 0.756 & & & 0.359 & & & 0.86 & \\
\hline & s11-20 & 0.066 & & 0.379 & & & 0.272 & & & 0.603 & & & 0.863 & & & 0.93 & \\
\hline & s21-100 & 0.616 & & 0.865 & & & 0.903 & & & 0.203 & & & 0.142 & & & 0.38 & \\
\hline & s101-200 & 0.390 & & 0.022 & increase & increase & 0.063 & & & 0.001 & increase & increase & 0.419 & & & 0.24 & \\
\hline & s201-500 & 0.129 & & 0.016 & similar & increase & 0.075 & & & 0.299 & & & 0.181 & & & 0.47 & \\
\hline & $s>500$ & 0.131 & & 0.601 & & & 0.171 & & & 0.645 & & & 0.327 & & & 0.89 & \\
\hline \multirow[t]{6}{*}{ Morphology } & Soft & 0.250 & & 0.330 & & & 0.456 & & & 0.101 & & & 0.533 & & & 0.77 & \\
\hline & Tunic & 0.118 & & 0.223 & & & 0.312 & & & 0.454 & & & 0.431 & & & 0.81 & \\
\hline & Chitin & 0.203 & & 0.045 & similar & increase & 0.034 & similar & increase & 0.619 & & & 0.927 & & & 0.78 & \\
\hline & Crustose & & & & & & & & & & & & & & & & \\
\hline & Cushion & & & & & & & & & & & & & & & & \\
\hline & Stalked & & & & & & & & & & & & & & & & \\
\hline \multirow[t]{4}{*}{ Longevity } & Long $<1$ & 0.000 & higher & 0.004 & similar & increase & 0.062 & & & 0.491 & & & 0.078 & & & 0.077 & \\
\hline & Long1-3 & 0.006 & higher & 0.018 & increase & increase & 0.019 & increase & increase & 0.026 & increase & increase & 0.976 & & & 0.247 & \\
\hline & Long3-10 & 0.500 & & 0.905 & & & 0.409 & & & 0.730 & & & 0.139 & & & 0.055 & \\
\hline & Long $>10$ & 0.167 & & 0.794 & & & 0.435 & & & 0.405 & & & 0.053 & & & 0.861 & \\
\hline \multirow[t]{2}{*}{ LarvalDevLoc } & LD_Pk & 0.777 & & 0.719 & & & 0.852 & & & 0.152 & & & 0.036 & increase & ncrease & 0.128 & \\
\hline & LD_LC & 0.250 & & 0.183 & & & 0.171 & & & 0.919 & & & 0.968 & & & 0.405 & \\
\hline
\end{tabular}




\begin{tabular}{|c|c|c|c|c|c|c|c|c|c|c|c|c|c|c|c|c|c|}
\hline \multirow{3}{*}{ Trait } & \multirow{3}{*}{$\begin{array}{l}\text { Modalit } \\
\mathbf{y} \\
\text { LD_Direct }\end{array}$} & \multicolumn{2}{|c|}{ Situation 1999} & \multicolumn{3}{|c|}{$\begin{array}{l}\text { Before - after ( } 2000 \text { - } \\
\text { 2014) }\end{array}$} & \multicolumn{3}{|c|}{ Before - after (2006) } & \multicolumn{3}{|c|}{ Before - after (2011) } & \multicolumn{3}{|c|}{ Before - after (2014) } & \multicolumn{2}{|c|}{ Trend ratio } \\
\hline & & pvalue & Inside & pvalue & inside & outside & pvalue & inside & outside & pvalue & inside & $\begin{array}{l}\text { outsid } \\
\text { e }\end{array}$ & pvalue & inside & $\begin{array}{l}\text { outsid } \\
\text { e }\end{array}$ & pvalue & Inside \\
\hline & & 0.000 & higher & 0.001 & decrease & increase & 0.002 & increase & increase & 0.078 & & & 0.002 & increase & increase & 0.003 & less increase \\
\hline \multirow[t]{4}{*}{ EggDevLoc } & Egg_asex & 0.321 & & 0.705 & & & 0.313 & & & 0.900 & & & 0.138 & & & 0.871 & \\
\hline & Egg_Pel & 0.408 & & 0.378 & & & 0.518 & & & 0.059 & & & 0.071 & & & 0.194 & \\
\hline & Egg_Ben & 0.049 & higher & 0.242 & & & 0.379 & & & 0.143 & & & 0.162 & & & 0.201 & \\
\hline & Egg_Bro & 0.051 & & 0.040 & increase & increase & 0.049 & increase & increase & 0.842 & & & 0.265 & & & 0.396 & \\
\hline \multirow[t]{6}{*}{ LivingHabit } & LH_Tube & 0.067 & & 0.226 & & & 0.194 & & & 0.055 & & & 0.719 & & & 0.089 & \\
\hline & LH_Burrow & 0.243 & & 0.695 & & & 0.165 & & & 0.897 & & & 0.000 & increase & increase & 0.001 & $\begin{array}{l}\text { larger } \\
\text { increase }\end{array}$ \\
\hline & LH_Free & 0.002 & higher & 0.006 & similar & increase & 0.005 & similar & increase & 0.061 & & & 0.240 & & & 0.109 & \\
\hline & LH_Crev & 0.471 & & 0.266 & & & 0.229 & & & 0.222 & & & 0.719 & & & 0.222 & \\
\hline & LH_Epi & 0.191 & & 0.006 & similar & increase & 0.013 & similar & increase & 0.006 & increase & increase & 0.079 & & & 0.583 & \\
\hline & LH_Att & 0.157 & & 0.670 & & & 0.547 & & & 0.942 & & & 0.950 & & & 0.684 & \\
\hline \multirow[t]{4}{*}{ SedPos } & spSurf & 0.000 & higher & 0.013 & increase & increase & 0.003 & similar & increae & 0.388 & & & 0.509 & & & 0.027 & less increase \\
\hline & sp0-5 & 0.291 & & 0.375 & & & 0.707 & & & 0.137 & & & 0.244 & & & 0.726 & \\
\hline & sp6-10 & 0.543 & & 0.860 & & & 0.282 & & & 0.636 & & & 0.169 & & & 0.069 & \\
\hline & $s p>10$ & 0.386 & & 0.022 & similar & increase & 0.020 & increase & increase & 0.022 & increase & increase & 0.565 & & & 0.641 & \\
\hline \multirow[t]{6}{*}{ FeedingMode } & F_Susp & 0.143 & & 0.952 & & & 0.582 & & & 0.452 & & & 0.004 & increase & increase & 0.217 & \\
\hline & F_Sdep & 0.142 & & 0.127 & & & 0.158 & & & 0.177 & & & 0.599 & & & 0.635 & \\
\hline & F_Subdep & 0.134 & & 0.120 & & & 0.161 & & & 0.232 & & & 0.708 & & & 0.452 & \\
\hline & F_Scav & 0.100 & & 0.229 & & & 0.142 & & & 0.158 & & & 0.934 & & & 0.544 & \\
\hline & F_pred & 0.040 & higher & 0.185 & & & 0.128 & & & 0.434 & & & 0.796 & & & 0.433 & \\
\hline & F_par & 0.195 & & 0.110 & & & 0.212 & & & 0.486 & & & 0.229 & & & 0.318 & \\
\hline \multirow[t]{4}{*}{ Mobility } & ses & 0.840 & & 0.746 & & & 0.670 & & & 0.562 & & & 0.011 & increase & increase & 0.327 & \\
\hline & swim & 0.000 & higher & 0.000 & similar & increase & 0.001 & similar & increase & 0.026 & increase & increase & 0.007 & increase & increase & 0.011 & less increase \\
\hline & $\mathrm{ccc}$ & 0.003 & higher & 0.014 & similar & increase & 0.004 & similar & increase & 0.265 & & & 0.171 & & & 0.021 & decrease \\
\hline & burrow & 0.531 & & 0.017 & similar & increase & 0.106 & similar & increase & 0.043 & increase & increase & 0.702 & & & 0.309 & \\
\hline
\end{tabular}




\begin{tabular}{|c|c|c|c|c|c|c|c|c|c|c|c|c|c|c|c|c|c|}
\hline \multirow[b]{2}{*}{ Trait } & \multirow[b]{2}{*}{$\begin{array}{l}\text { Modalit } \\
\mathbf{y}\end{array}$} & \multicolumn{2}{|c|}{ Situation 1999} & \multicolumn{3}{|c|}{$\begin{array}{l}\text { Before - after ( } 2000 \text { - } \\
\text { 2014) }\end{array}$} & \multicolumn{3}{|c|}{ Before - after (2006) } & \multicolumn{3}{|c|}{ Before - after (2011) } & \multicolumn{3}{|c|}{ Before - after (2014) } & \multicolumn{2}{|c|}{ Trend ratio } \\
\hline & & pvalue & Inside & pvalue & inside & outside & pvalue & inside & outside & pvalue & inside & $\mathbf{e}^{\text {outsid }}$ & pvalue & inside & $\begin{array}{l}\text { outsid } \\
\text { e }\end{array}$ & pvalue & Inside \\
\hline Bioturbators & BT_Diff & 0.083 & & 0.006 & decrease & increase & 0.037 & similar & increase & 0.092 & increase & increase & 0.706 & & & 0.56 & \\
\hline & BT_Surf & 0.238 & & 0.341 & & & 0.579 & & & 0.319 & & & 0.076 & & & 0.733 & \\
\hline & BT_Up & 0.581 & & 0.778 & & & 0.920 & & & 0.638 & & & 0.646 & & & 0.665 & \\
\hline & BT_Down & 0.944 & & 0.189 & & & 0.836 & & & 0.499 & & & 0.809 & & & 0.475 & \\
\hline & BT_None & 0.301 & & 0.123 & & & 0.074 & increase & increase & 0.214 & & & 0.935 & & & 0.697 & \\
\hline
\end{tabular}


Development of modalities are shown that show a significant different development inside the $500 \mathrm{~m}$ zone for at least one time interval, see table 1. Significance after Bonferroni correction $(p<0.001)$.
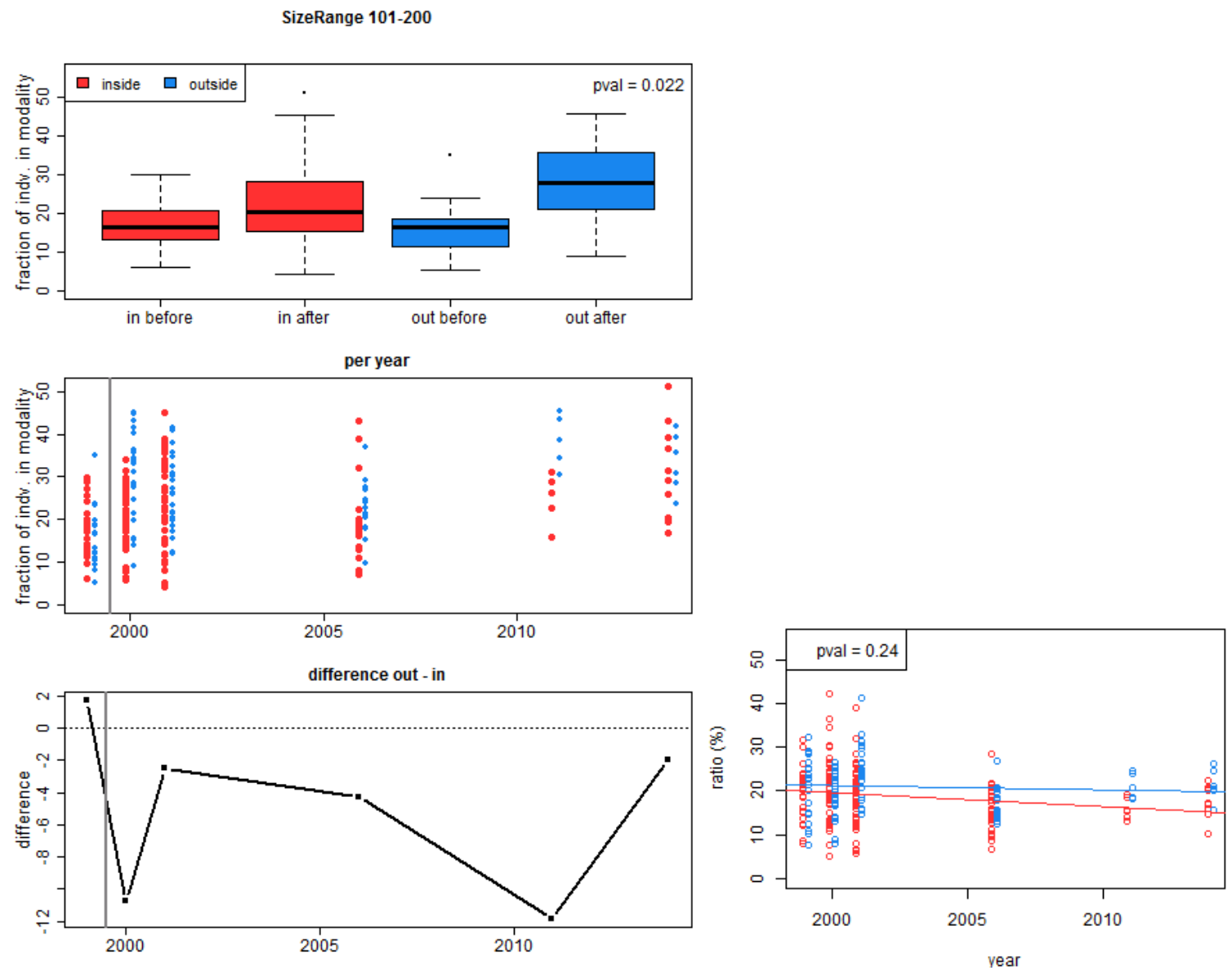

Figure A6.1. Development of the modality Size range - 101-200 in the inside and outside area. Toppanel left figure boxplot of before-after for inside and outside area. Middle panel lef figure dotplot of inside and outside area per year. Lower panel left figure mean difference between inside and outside area per year. Right figure linear relationship between time and modality, $p$ value represents interaction time vs sampling group (inside / outside 500m. zone). 

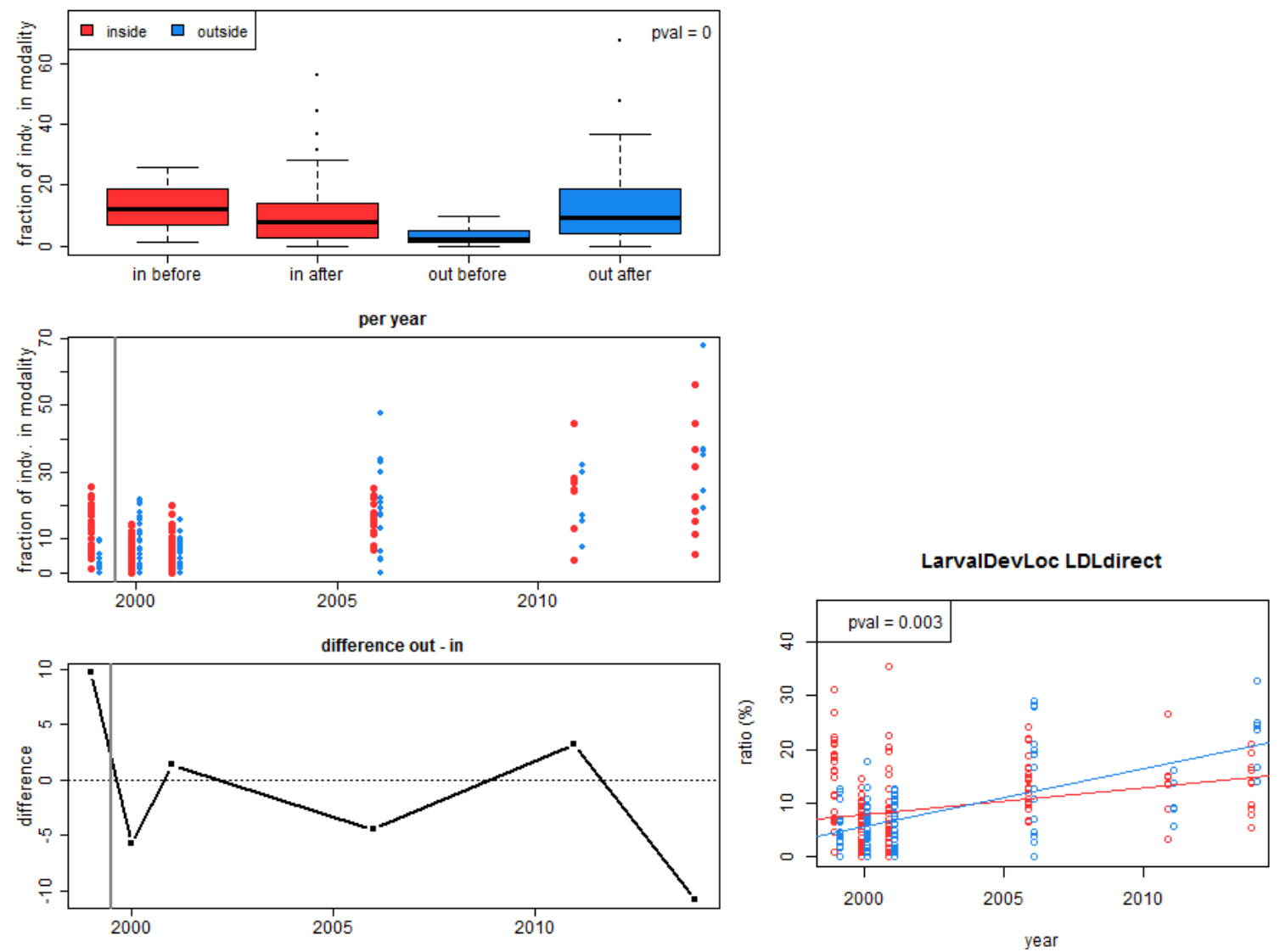

Figure A6.2. Development of the modality Larval Development Location - direct in the inside and outside area. Toppanel left figure boxplot of before-after for inside and outside area. Middle panel lef figure dotplot of inside and outside area per year. Lower panel left figure mean difference between inside and outside area per year. Right figure linear relationship between time and modality, $\mathrm{p}$ value represents interaction time vs sampling group (inside / outside 500m. zone). 

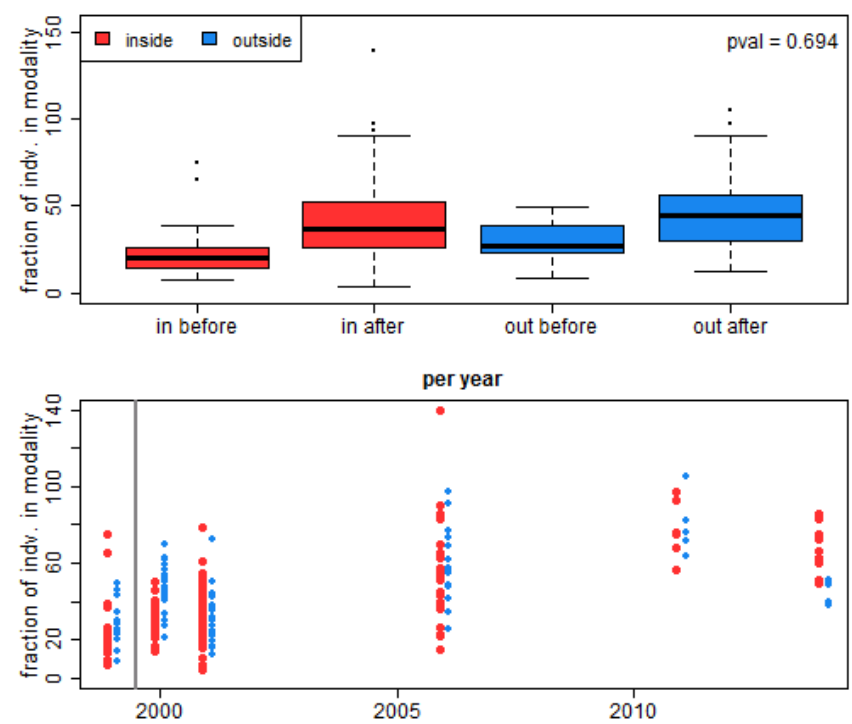

LivingHabit LHburrow

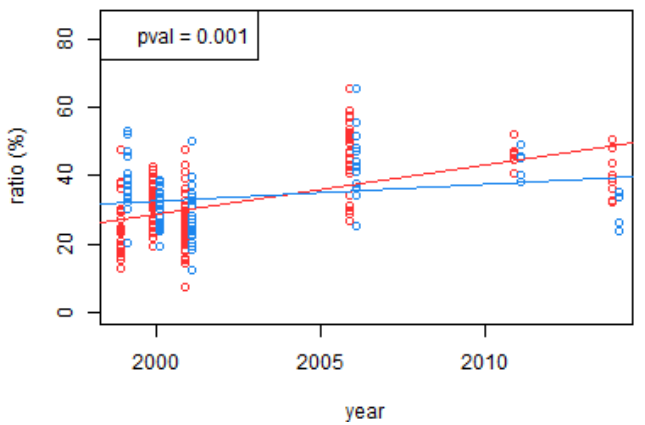

Figure A6.3. Development of the modality Living Habitat - burrow in the inside and outside area. Toppanel left figure boxplot of before-after for inside and outside area. Middle panel lef figure dotplot of inside and outside area per year. Lower panel left figure mean difference between inside and outside area per year. Right figure linear relationship between time and modality, $\mathrm{p}$ value represents interaction time vs sampling group (inside / outside 500m. zone). 


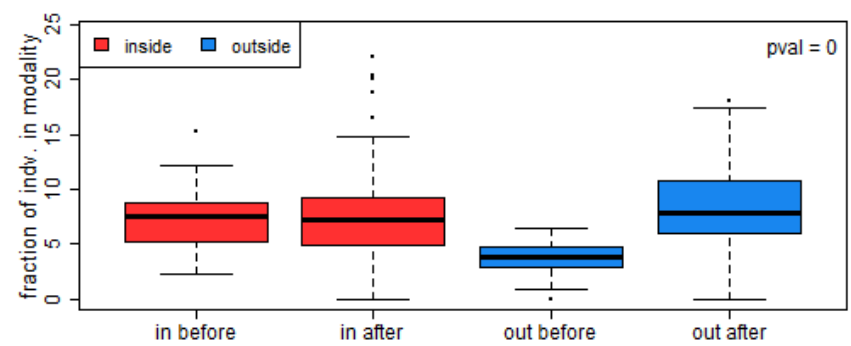

per year

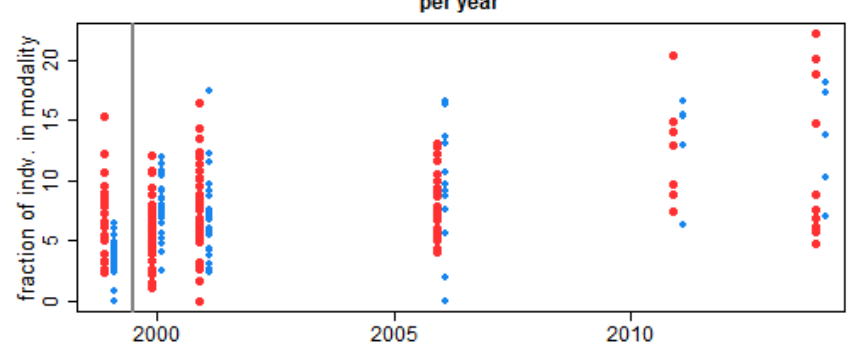

Mobility Mswim
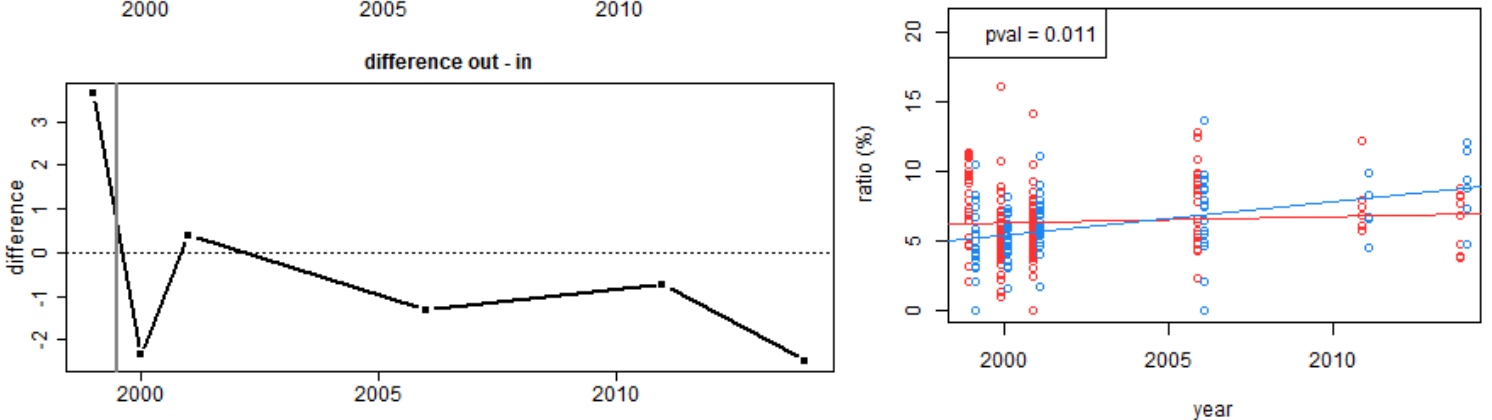

Figure A6.5. Development of the modality Mobility - swim in the inside and outside area. Toppanel left figure boxplot of before-after for inside and outside area. Middle panel lef figure dotplot of inside and outside area per year. Lower panel left figure mean difference between inside and outside area per year. Right figure linear relationship between time and modality, $\mathrm{p}$ value represents interaction time vs sampling group (inside / outside $500 \mathrm{~m}$. zone). 
Wageningen Marine Research

T +31 (0)317 480900

E: marine-research@wur.nl

www.wur.eu/marine-research

Visitors' address

- Ankerpark 27, 1781 AG Den Helder

- Korringaweg 5, 4401 NT Yerseke

- Haringkade 1, 1976 CP IJ muiden
Wageningen Marine Research is the Netherlands research institute established to provide the scientific support that is essential for developing policies and innovation in respect of the marine environment, fishery activities, aquaculture and the maritime sector.

\section{Wageningen University \& Research:}

is specialised in the domain of healthy food and living environment.

\section{The Wageningen Marine Research vision}

'To explore the potential of marine nature to improve the quality of life'

\section{The Wageningen Marine Research mission}

- To conduct research with the aim of acquiring knowledge and offering advice on the sustainable management and use of marine and coastal areas.

- Wageningen Marine Research is an independent, leading scientific research institute

Wageningen Marine Research is part of the international knowledge organisation Wageningen UR (University \& Research centre). Within Wageningen UR, nine specialised research institutes of the Stichting Wageningen Research Foundation have joined forces with Wageningen University to help answer the most important questions in the domain of healthy food and living environment. 